\title{
Plankton studies in Buzzards Bay, Massachusetts, USA. VI. Phytoplankton and water quality, 1987 to 1998
}

\author{
Jefferson T. Turner*, David G. Borkman, Jean A. Lincoln, David A. Gauthier, \\ Christian M. Petitpas
}

School for Marine Science and Technology, University of Massachusetts Dartmouth, 706 South Rodney French Boulevard, New Bedford, Massachusetts 02744, USA

\begin{abstract}
From October 1987 through September 1998, phytoplankton composition, inorganic nutrients, temperature, salinity, water clarity, and chlorophyll a (chl a) + phaeopigments were monitored during 141 monthly cruises in Buzzards Bay, Massachusetts, USA. There were large seasonal and interannual variations in nitrate, silicate and phytoplankton abundance and composition. There were no consistent interannual patterns of recurrent spring blooms, measured as either chl $a$ or phytoplankton cell abundance. Rather, blooms of various taxa were sporadic, particularly diatom blooms in the late summer and fall. Other parameters were similar bay-wide on a given day, and over seasons and years for stations away from New Bedford Harbor, but concentrations of ammonium, phosphate, and chl a were elevated at the New Bedford sewage outfall, prior to its conversion to secondary treatment in September 1996. After conversion, increased water transparency and decreased levels of ammonium indicated improved water quality at the outfall. Bay-wide chl a and nitrate had significant declines over time from the late 1980s to the late 1990s. There were no significant linear trends with time for annual means of temperature, but there was a significant trend of increased


than reported in other coastal waters of New England, due to preservation that did not destroy the delicate microflagellates and phytoflagellates which dominated phytoplankton abundance. Potentially harmful algal species included diatoms of the genus Pseudo-nitzschia, and the dinoflagellate Alexandrium fundyense. Buzzards Bay is a favorable habitat for phytoplankton in that it is wellmixed and well-illuminated, and nutrient-replete.
\end{abstract}

KEY WORDS: Buzzards Bay $\cdot$ Phytoplankton $\cdot$ Nutrients $\cdot$ Estuary $\cdot$ Water quality $\cdot$ Long-term trends Resale or republication not permitted without written consent of the publisher

\section{INTRODUCTION}

Estuaries are variable habitats; understanding the plankton dynamics of such systems requires long-term baseline ecological data in order to separate what is 'abnormal' from the variability that is 'normal.' Longterm data on phytoplankton community structure and dynamics is needed for understanding eutrophication and harmful algal blooms (HABs), but most studies of phytoplankton assemblages have been of limited duration, typically a single year. Where multi-year phytoplankton data exist, interannual variability is frequently substantial (Smayda et al. 2004 and references therein), and related to both short-term meteorological and climatic variation, and to longer-term anthropogenic modification of nutrient regimes.

Comparisons of phytoplankton communities in different waters are often complicated by differences in methodology. These include different microscopic counting techniques and levels of taxonomic resolution, and/or use of different preservatives which affect the types of phytoplankton (thecate vs. athecate) that survive preservation in formalin versus Lugol's or Utermöhl's solution, respectively. The use of formalin preservation in most studies prior to recent years resulted in data that included mainly diatoms and the- 
cate dinoflagellates, which do not disintegrate upon formalin preservation (e.g. Turner \& Hopkins 1974). Studies of either live phytoplankton samples, or those using preservatives that do not destroy most athecate phytoplankton, have revealed that small athecate cells (typically designated as 'microflagellates') often dominate phytoplankton abundance (Durbin et al. 1975), particularly during warmer periods. High abundance of athecate microflagellates was found in several recent studies of phytoplankton assemblages in coastal waters from the northeastern United States (Narragansett Bay, Rhode Island: Karentz \& Smayda 1984, 1998, Smayda 1983, 1998; Peconic Bay, Long Island, New York: Turner et al. 1983; Boston Harbor, Massachusetts Bay, and Cape Cod Bay, Massachusetts: numerous reports from the Massachusetts Water Resources Authority at www.mwra.state.ma.us/harbor/ enquad/trlist.html).

It is often difficult to compare responses of estuarine phytoplankton assemblages to natural interannual variability, anthropogenic modification and climatic change. Important (athecate) taxa may bloom but go unrecorded due to preservation artifacts. Also, 'textbook' phenomena such as spring (usually diatom) blooms are probably not the rule, since there are areas where diatom blooms are recurrent in seasons other than spring, or occur sporadically throughout the year. Thus, possible phenological changes in the timing of spring blooms that may be associated with long-term warming in temperate regions (Edwards \& Richardson 2004) may be difficult to understand or predict if understanding of the phytoplankton community is incomplete or incorrect.

Buzzards Bay, Massachusetts (Fig. 1) is one of the largest estuaries in the northeastern United States, but until recently, information on the ecology of this system has been surprisingly limited. Despite the fact that studies in the bay date back over a century (references in Turner \& Borkman 1993), information on such basic parameters as plankton assemblages and inorganic nutrient distributions has lacked sufficient temporal and spatial coverage to quantify trends, particularly for the open waters of the bay.

There has been a recent resurgence of interest in Buzzards Bay, partly due to concerns about pollution. Buzzards Bay has been classified by NOAA/EPA (1989) as high in susceptibility to concentrating particulate and dissolved pollutants due to large overall estuarine volume relative to comparatively low volume of freshwater inflow that would flush the estuary. Cultural eutrophication of many Buzzards Bay embayments is proceeding (Costa et al. 1996, Howes \& Goeringer 1996, Howes et al. 1999). Such nutrient enrichment has been linked to a possible global increase in toxic or noxious phytoplankton blooms (Smayda et al. 2004, Granéli \& Turner 2006).

Like other urbanized estuaries, Buzzards Bay has portions that are becoming increasingly eutrophic. A conspicuous area is New Bedford Harbor, where the city's sewage outfall discharged $>90000 \mathrm{~m}^{3} \mathrm{~d}^{-1}$ of poorly treated effluent that was, until 1996, nominally primary treated (chlorination plus putative separation of solids from liquids). In fact, the effluent at this time was visibly discolored with fine particles of sludge, and oily with road runoff. Beginning in September 1996, sewage treatment was converted to secondary treatment, with better separation of solids from liquids, and reduction of nitrogen through biodegradation during settling. However, Buzzards Bay is large $\left(590 \mathrm{~km}^{2}\right)$,

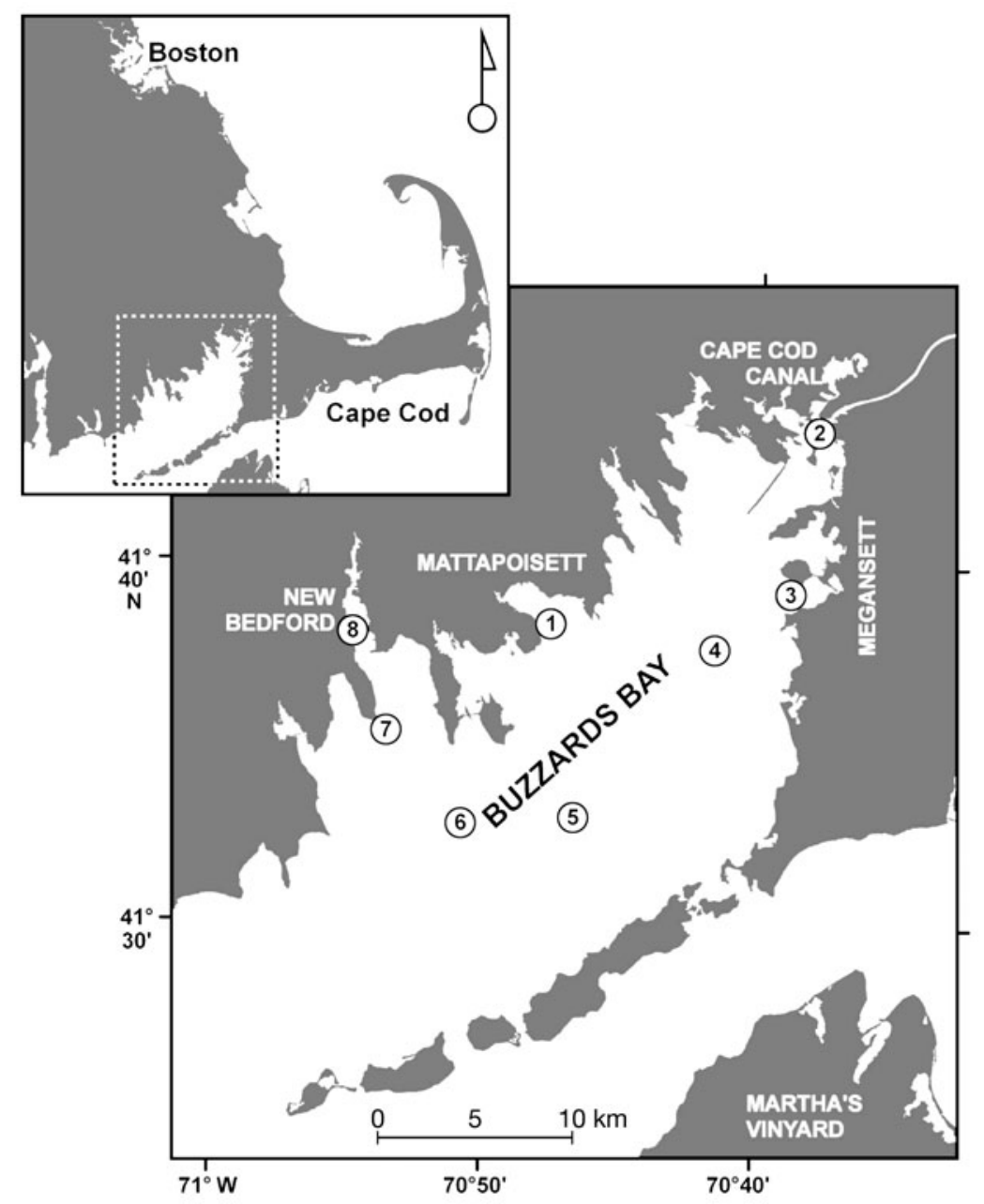

Fig. 1. Location of sampling stations in Buzzards Bay, Massachusetts, USA 
and most offshore areas have received little anthropogenic discharge and little freshwater runoff compared to other nearby estuaries such as Narragansett Bay. In addition, due to shallow depths $(<20 \mathrm{~m})$ and dynamic wind and tidal mixing, resuspension of bottom sediments frequently injects regenerated nutrients from the benthos back into the water column (Rhoads et al. 1975, Roman 1978). Thus, the nutrient regime of Buzzards Bay is complicated, and it is important to clarify temporal and spatial patterns of nutrients and phytoplankton throughout the estuary.

Beginning in October 1987, a program was initiated for monitoring environmental parameters in Buzzards Bay to establish temporal and spatial trends of hydrography, water quality and plankton community structure. This monitoring has quantified temperature, salinity, water clarity, inorganic nutrients (ammonium, nitrate + nitrite, phosphate, silicate), chlorophyll a $(\mathrm{chl} a)+$ phaeopigments, and bacterioplankton abundance on monthly cruises at 8 stations throughout the bay (Fig. 1). Samples have also been collected and preserved for quantitative taxonomic analyses of abundance and community composition of phytoplankton, zooplankton, and ichthyoplankton. Additional parameters measured at some but not all stations, or for part but not all of the sampling period, included dissolved oxygen, primary productivity (photosynthetic rates) and age and growth of larval fish. From October 1987 to October 1998, there was a monitoring cruise every calendar month, year-round, with no interruptions (see Appendix 1 in MEPS Supplementary Material available at www.int-res.com/articles/suppl/m376 p103_app.pdf).

Thus far, the monitoring program has produced theses, reports and publications from the early years of the study (1987 to 1993). These include studies of phytoplankton pigments and nutrients (Borkman \& Turner 1993), hydrography and bacterioplankton (Turner \& Borkman 1993), phytoplankton abundance and composition (Borkman et al. 1993, Borkman 1994, Pierce \& Turner 1994a, Turner et al. 1995), phytoplankton primary production (Hill 1998), tintinnid and ciliate abundance and composition (Pierce \& Turner 1994b), ichthyoplankton abundance, composition and growth (Chute \& Turner 2001, Gauthier et al. 2008), and copepod feeding (Nakamura \& Turner 1997) However, an overview of long-term trends and patterns in temperature, hydrography, water clarity, nutrient concentrations and phytoplankton abundance and community composition has not previously been presented.

There are several reasons why it is important to record fluctuations and/or changes in phytoplankton abundance and community composition. Various phytoplankton taxa respond differentially to such parameters as light, temperature, and concentrations of various nutrients, as these driving parameters change with season, interannually, and/or in response to anthropogenic manipulation. The phytoplankton community responds with changes in relative and/or absolute abundance of various taxa. As water quality deteriorates, certain 'nuisance' taxa may be expected to flourish. Conversely, if water quality improves, and conditions near the New Bedford sewage outfall indicate that it has, then the phytoplankton community might be expected to also reflect such changes.

Although we took 11 yr (1987 to 1998) of concurrently collected monthly nutrient and phytoplankton samples, these had been previously analyzed for community composition only for 1987-88 (Borkman et al. 1993, Borkman 1994, Pierce \& Turner 1994a, Turner et al. 1995). Thus, we examined selected archived phytoplankton samples from 1987 to 1998 for community composition and abundance.

Several important observations have already resulted from our first year of phytoplankton analyses (19871988). Dinoflagellates bloom regularly over the annual cycle in Buzzards Bay. Such blooms usually follow diatom blooms, which have stripped the water of silicate, but have left concentrations of nitrogen and phosphorus sufficient to support blooms of dinoflagellates or other algae that do not require silicate (Borkman et al. 1993). Thus, the typical 'spring bloom' can actually be 'spring blooms' of first diatoms, and later dinoflagellates or other non-silicate-requiring species. Further, the major diatom bloom of the year did not come in spring, but rather was a bloom of Skeletonema spp. in late August-early September. This bloom followed a period of silicate build-up in June and July, after depletion of silicate in the spring.

We also made the first recording of a bloom of Alexandrium fundyense (formerly Gonyaulax tamarensis and Alexandrium tamarense; see Anderson et al. 2005) in Buzzards Bay in summer 1988 (Pierce \& Turner 1994a, Turner et al. 1995). Although this dinoflagellate is well-known for causing red tides and shellfish toxicity in coastal waters of New England (Anderson 1997), surprisingly it had never been previously recorded to bloom in Buzzards Bay, likely because there had been no phytoplankton abundance and community composition monitoring in Buzzards Bay prior to the onset of our monitoring program in 1987. Pierce \& Turner (1994a) and Turner et al. (1995) reported that $A$. fundyense was a recurrent component of the phytoplankton of Buzzards Bay from June to October 1988. Although it was found at all stations, it was more typical of the northern area and the Cape Cod Canal. Typical abundances of $A$. fundyense were

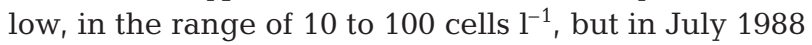
it bloomed in the inner harbor of New Bedford at levels of 3000 cells $\mathbf{l}^{-1}$. It is not known if this bloom produced 
shellfish toxicity since New Bedford Harbor had been closed to shellfishing for nearly a century due to sewage contamination and shellfish tissue was not analyzed for toxin. However, with improving water quality in New Bedford Harbor due to sewage remediation, there has been recent limited opening of the outer harbor to shellfishing since conversion from primary to secondary treatment. If $A$. fundyense is a regular spring/summer component of the phytoplankton in New Bedford Harbor and Buzzards Bay, then opening of additional areas to shellfishing should be coupled with increased monitoring of both water and shellfish for paralytic shellfish poisoning (PSP) toxins.

A major aspect of our studies was quantitative taxonomic analyses of phytoplankton community composition. Since collections were made from 8 stations at 3 depths per station (surface, mid-depth, and bottom) on each of 141 cruises, we had $>3000$ archived phytoplankton samples for the 1987 to 1998 period. However, we did not need to analyze all of them, for several reasons. Comparisons presented in Borkman (1994) revealed that for the 1987 to 1988 samples (Cruises 1 to 17), because the water column in Buzzards Bay was routinely isothermal, there were few vertical discontinuities in phytoplankton abundance or community composition. Thus, by analyzing surface samples only, we could get virtually all of the information that might be obtained by the laborious analyses of all samples. Further, even though 8 stations were analyzed per cruise (see Fig. 1), Borkman (1994) found that the major gradient of change of phytoplankton abundance and composition was along a line from inner New Bedford Harbor (Stn 8), to the New Bedford sewage outfall in the outer harbor (Stn 7), to the middle of Buzzards Bay (Stn 6). Thus, by analyzing surface samples from each of these 3 stations, we could generally characterize the phytoplankton of Buzzards Bay by analyzing 36 samples per year. For the 10 years between October 1988 (when Borkman's 1994 analyses ended) and September 1998 (the end of our phytoplankton analyses), a total of 372 phytoplankton samples (for Cruises 18 to 141) were quantified for the present study.

\section{MATERIALS AND METHODS}

Stations. Samples were collected at 8 stations throughout Buzzards Bay (Fig. 1). Three of these (Stns 4, 5, and 6) were at buoys along the central axis of the bay at depths of 10 to $15 \mathrm{~m}$, depending on tide. Stn 2 (depth $=8$ to $12 \mathrm{~m}$ depending on tide) was at the southwestern end of the Cape Cod Canal. At this station there are strong tidal currents (up to 4 knots) which change direction every $6 \mathrm{~h}$. In order to complete sampling of the entire bay in $1 \mathrm{~d}$, all stations were sam- pled upon arrival at a station, irrespective of the state of the tide. Stns 1 and 3 were in the shallow embayments of Mattapoisett and Megansett Harbors at depths of 5 to $8 \mathrm{~m}$. Stn 7 (depth $=6$ to $8 \mathrm{~m}$ depending on tide) was over the subsurface outfall of the sewage plant of New Bedford. Stn 8 (depth $=8 \mathrm{~m}$ ) was in the main channel of the inner harbor of New Bedford. This harbor is almost completely enclosed by a stone hurricane dike; thus, circulation is restricted relative to the rest of the bay (Signell 1987, Geyer \& Dragos 1990). All stations were precisely located by Loran or GPS coordinates. Water column depths at a given station varied with tidal range, which in Buzzards Bay ranges from approximately 1.0 to $1.5 \mathrm{~m}$.

Sampling. Samples were collected at all 8 stations on each of 141 cruises between 1 October 1987 and 11 September 1998 (Appendix 1). All stations were sampled in a single day on each cruise. Cruises were monthly, except for October 1987, June to October 1988, and June to August 1989 when they were performed every $2 \mathrm{wk}$.

Temperature was measured at each station to the nearest $0.01^{\circ} \mathrm{C}$ with a Beckman temperature probe at $1 \mathrm{~m}$ intervals over the entire water column. Water transparency was measured with a $30 \mathrm{~cm}$ diameter white Secchi disk, with estimates to the nearest half meter. Water samples were collected with Niskin bottles from surface, mid-depth, and near-bottom depths. These samples were used for synoptic salinity, nutrient, chl $a$ + phaeopigment, and phytoplankton analyses (Cruises 1 to 141). Salinity was measured (to the nearest \%o) with a refractometer.

Light penetration. The $1 \%$ isolume depth (i.e. bottom of the euphotic zone) was calculated (in meters) from Secchi disk measurements by:

$$
\text { Isolume depth }=\ln (\text { fraction of light }) /(-k)
$$

where fraction of light is percent of that at the surface (i.e. 0.01 for $1 \%$ ), and extinction coefficient $(k)=1.44$ / Secchi depth (m).

Nutrients. At surface, mid-depth and bottom depths at all stations on all cruises, concentrations of ammonium, nitrate + nitrite, phosphate and silicate were measured ( $\mathrm{n}=3384$ samples for each nutrient). To avoid measuring levels of nutrients in plankton or other particulates along with dissolved nutrients, all samples were pre-filtered aboard ship through Whatman GFC glass fiber filters. Blanks on unfiltered water were performed to correct for any silicon additions from the filters. Nutrient samples were kept on ice until return to the laboratory $(<1 \mathrm{~h}$ after docking), and frozen $\left(-80^{\circ} \mathrm{C}\right)$ in the laboratory prior to analyses.

Analyses were performed with either a Technicon Autoanalyzer 2 (Cruises 1 to 17) or an Alpkem RFA300 Elemental Analyzer (Cruises 16 to 141). An inter- 
calibration of both instruments on all samples from Cruises 16 and 17 revealed comparable data. The chemistry for analyses with both instruments was essentially that of Parsons et al. (1984).

Chl a + phaeopigments. Samples from surface, middepth and bottom depths at all stations on all cruises ( $\mathrm{n}=3384$ ) were filtered aboard ship through Whatman GFC glass fiber filters. Either $100 \mathrm{ml}$ or usually $200 \mathrm{ml}$ was filtered, and filters were coated immediately with $1 \% \mathrm{MgCO}_{3}$ to prevent pigment degradation. Filters were individually wrapped in aluminum foil and kept on ice until return to the laboratory. Either the night after each cruise, or the next day (after freezing overnight), filters were disintegrated in $90 \%$ acetone and kept for an additional day in a freezer in the dark for maximum extraction of pigments. Chl a + phaeopigment analyses were done with a Turner Designs Model 10 fluorometer according to the methodology of Parsons et al. (1984). Phaeopigment analyses were after acidification with 2 drops of $1 \mathrm{~N} \mathrm{HCl}$.

Phytoplankton. Phytoplankton samples were collected at surface, mid-depth and bottom depths with Niskin bottles. Approximately $800 \mathrm{ml}$ of raw seawater from each depth was preserved in $0.7 \%$ Utermöhl's iodine solution (formula in Guillard 1973). Phytoplankton counts were made on samples concentrated by gravimetric sedimentation, usually from approximately $800 \mathrm{ml}$ to a final concentrate of $50 \mathrm{ml}$. Samples were counted in Sedgwick-Rafter counting chambers. Use of an Olympus BH-2 or B201 phase-contrast microscope equipped with long-working-distance objectives $<4 \mathrm{~cm}$ in length allowed use of the Sedgwick-Rafter cells at both low and high magnifications (normally only low magnification is possible).

Phytoplankton analyses were performed on each sample at both high $(400 \times$ or $500 \times)$ and low $(200 \times$ or $250 \times$ ) magnifications. This was to accurately quantify abundances of small cells that might not have been seen in routine examinations at the lower magnifications, but to also quantify abundances of larger, albeit rarer cells that might have been missed by examining only a smaller aliquot, the size of which was dictated by abundance of smaller, more abundant cells. Counts were made at high magnification until enough grids (measured by a calibrated Whipple Disc in the eyepiece) had been counted to give at least 400 cells, thereby giving a precision of at least $\pm 10 \%$ (Guillard 1973). Counts were then made on each sample at low magnification, counting all cells in a $0.5 \mathrm{ml}$ volume, and recording all taxa not encountered in the high magnification count. All cells were identified to species, or if species identification was uncertain to the lowest possible taxon, using a phase-contrast compound microscope.
Two different compound microscopes were used: Olympus BH3 and Olympus B201 phase-contrast microscopes. Since the BH3 had a $1.25 \times$ column magnifier, that meant that magnifications on the $20 \times$ and $40 \times$ objectives (with $10 \times$ oculars) would have actually been $250 \times$ and $500 \times$, respectively. Since the B201 had no $1.25 \times$ column magnifier, then actual magnifications with $20 \times$ and $40 \times$ objectives (and $10 \times$ oculars) were $200 \times$ and $400 \times$. These differences in magnification, and their effects on the areas of the grids counted with the 2 different microscopes, were accounted for in the calculations for phytoplankton abundance.

Phytoplankton analyses were made on 372 samples from Stns 6, 7, and 8 (Fig. 1). In all but a few cases, samples that were analyzed were from surface depths. However, in 4 cases, surface samples were unavailable, so counts for those stations came from mid-depth or bottom samples. These samples included Cruise 18, Stn 8 (bottom), Cruise 31, Stn 6 (mid-depth), Cruise 37 , Stn 8 (mid-depth), and Cruise 81, Stn 6 (mid-depth).

Long-term trend analysis. The observations presented here were analyzed for trends over time using linear regression. This preliminary trend test was applied to chl $a$, ammonium, nitrate + nitrite, phosphate, silicate, surface temperature, and Secchi depth observations at all 24 station-depth combinations. Observations were checked for approximation of a Gaussian distribution prior to trend analysis using the Kolmogorov-Smirnov test. Data sets that did not have an approximately Gaussian distribution were $\ln (x+1)$ transformed prior to analysis. Linear regression trend analysis was performed using SAS 9.1 for Windows (SAS 2004). The linear trend test was used to identify variables having linear changes during 1987 to 1998.

\section{RESULTS}

Summary data (means and ranges) for light penetration, and chl $a$ and nutrient data are presented in Table 1. Summary data for phytoplankton abundance and percentage composition are presented in Table 2. A list of phytoplankton taxa recorded is presented in Appendix 2 in MEPS Supplementary Material available at www.int-res.com/articles/suppl/m376p103_app. pdf.

\section{Temperature}

There was pronounced seasonality of surface temperature (range $=-2.0$ to $27.3^{\circ} \mathrm{C}$ ) (Fig. 2) during all years of the study. Due to wind and tidal mixing (Sankaranarayanan 2007) and shallow depths, the water column was usually isothermal with $<1^{\circ} \mathrm{C}$ varia- 
Table 1. Means and ranges for water transparency, bacterioplankton, and chlorophyll a ( $\mathrm{chl}$ a) and nutrient data during Cruises 1 to 141. DIN: dissolved inorganic nitrogen (nitrate + nitrite + ammonium)

\begin{tabular}{|c|c|c|c|}
\hline Parameter and Stn & Mean & Max. & Min. \\
\hline \multicolumn{4}{|l|}{ Secchi depth (m) } \\
\hline $1-6$ & 4.3 & 12.0 & 1.5 \\
\hline 7 & 2.3 & 6.0 & 0.8 \\
\hline 8 & 2.9 & 5.5 & 1.0 \\
\hline All & 3.9 & 12.0 & 0.8 \\
\hline \multicolumn{4}{|c|}{$\%$ of water column in euphotic zone (\%) } \\
\hline $1-6$ & 94.65 & 100.00 & 45.73 \\
\hline 7 & 82.48 & 100.00 & 34.29 \\
\hline 8 & 90.48 & 100.00 & 40.00 \\
\hline All & 92.61 & 100.00 & 34.29 \\
\hline \multicolumn{4}{|l|}{ Chl a $\left(\mu g l^{-1}\right)$} \\
\hline $1-6$ & 5.00 & 22.37 & 0.10 \\
\hline 7 & 6.69 & 27.65 & 0.79 \\
\hline 8 & 12.84 & 64.66 & 0.92 \\
\hline All & 6.19 & 64.66 & 0.10 \\
\hline \multicolumn{4}{|c|}{ Nitrate + nitrite $(\mu \mathrm{M})$} \\
\hline $1-6$ & 0.81 & 6.57 & 0.00 \\
\hline 7 & 1.13 & 9.40 & 0.04 \\
\hline 8 & 1.03 & 4.34 & 0.04 \\
\hline All & 0.87 & 9.40 & 0.00 \\
\hline \multicolumn{4}{|l|}{ Ammonium $(\mu \mathrm{M})$} \\
\hline $1-6$ & 2.60 & 26.77 & 0.00 \\
\hline 7 & 6.97 & 70.53 & 0.14 \\
\hline 8 & 4.09 & 19.72 & 0.00 \\
\hline All & 3.35 & 70.53 & 0.00 \\
\hline \multicolumn{4}{|c|}{ Total DIN $\left(\mathrm{NO}_{3}+\mathrm{NO}_{2}+\mathrm{NH}_{4}\right)(\mu \mathrm{M})$} \\
\hline $1-6$ & 3.36 & 29.85 & 0.00 \\
\hline 7 & 8.05 & 70.68 & 0.16 \\
\hline 8 & 5.07 & 22.44 & 0.64 \\
\hline All & 4.16 & 70.68 & 0.00 \\
\hline \multicolumn{4}{|c|}{$\mathrm{NH}_{4}$ as \% of total DIN (\%) } \\
\hline $1-6$ & 75.37 & $>99.00$ & $<0.1$ \\
\hline 7 & 81.22 & $>99.00$ & $<0.1$ \\
\hline 8 & 75.25 & $>99.00$ & $<0.1$ \\
\hline All & 76.08 & $>99.00$ & $<0.1$ \\
\hline \multicolumn{4}{|l|}{ Silicate $(\mu \mathrm{M})$} \\
\hline $1-6$ & 6.47 & 70.11 & 0.10 \\
\hline 7 & 8.63 & 36.82 & 0.20 \\
\hline 8 & 9.05 & 61.34 & 0.10 \\
\hline All & 7.07 & 70.11 & 0.10 \\
\hline \multicolumn{4}{|l|}{ Phosphate $(\mu \mathrm{M})$} \\
\hline $1-6$ & 0.66 & 8.02 & 0.00 \\
\hline 7 & 2.58 & 27.03 & 0.08 \\
\hline 8 & 1.67 & 8.86 & 0.10 \\
\hline All & 1.04 & 27.03 & 0.00 \\
\hline
\end{tabular}

tion between temperatures measured at every meter between the surface and bottom except during summer (May or June through August or September). Although vertical profiles of temperature are not presented here, as shown by Turner \& Borkman (1993), using vertical profiles of temperature for summer of 1988, any thermal discontinuity was only near-bottom at some stations, and rarely $>4^{\circ} \mathrm{C}$ cooler than surface temperatures.
Table 2. Summary of phytoplankton abundance and percentage composition data during Cruises 18 to 141

\begin{tabular}{|c|c|c|c|}
\hline & Stn 6 & Stn 7 & Stn 8 \\
\hline \multicolumn{4}{|c|}{ Abundance (cells $\mathbf{l}^{-1}$ ) } \\
\hline \multicolumn{4}{|c|}{ Total phytoplankton } \\
\hline Mean & $3.06 \times 10^{6}$ & $5.11 \times 10^{6}$ & $5.35 \times 10^{6}$ \\
\hline Max. & $9.75 \times 10^{6}$ & $16.35 \times 10^{6}$ & $26.04 \times 10^{6}$ \\
\hline Min. & $12.54 \times 10^{3}$ & $665.36 \times 10^{3}$ & $1.28 \times 10^{6}$ \\
\hline \multicolumn{4}{|c|}{ Microflagellates } \\
\hline Mean & $2.64 \times 10^{6}$ & $4.03 \times 10^{6}$ & $3.54 \times 10^{6}$ \\
\hline Max. & $5.84 \times 10^{6}$ & $9.27 \times 10^{6}$ & $12.64 \times 10^{6}$ \\
\hline Min. & $479.14 \times 10^{3}$ & $644.95 \times 10^{3}$ & $688.59 \times 10^{3}$ \\
\hline \multicolumn{4}{|c|}{ Cryptomonads } \\
\hline Mean & $341.45 \times 10^{3}$ & $485.90 \times 10^{3}$ & $922.90 \times 10^{3}$ \\
\hline Max. & $1.59 \times 10^{6}$ & $2.69 \times 10^{6}$ & $9.41 \times 10^{6}$ \\
\hline Min. & 0 & 0 & 0 \\
\hline \multicolumn{4}{|l|}{ Diatoms } \\
\hline Mean & $96.52 \times 10^{3}$ & $585.89 \times 10^{3}$ & $748.84 \times 10^{3}$ \\
\hline Max. & $4.04 \times 10^{6}$ & $11.27 \times 10^{6}$ & $10.17 \times 10^{6}$ \\
\hline Min. & $1.10 \times 10^{3}$ & $0.28 \times 10^{3}$ & 0 \\
\hline \multicolumn{4}{|c|}{ Dinoflaqellates } \\
\hline Mean & $2.81 \times 10^{3}$ & $4.95 \times 10^{3}$ & $74.88 \times 10^{3}$ \\
\hline Max. & $29.47 \times 10^{3}$ & $50.59 \times 10^{3}$ & $2.19 \times 10^{6}$ \\
\hline Min. & 0 & 0 & 0 \\
\hline \multicolumn{4}{|l|}{ Other } \\
\hline Mean & $1.50 \times 10^{3}$ & $3.16 \times 10^{3}$ & $71.31 \times 10^{3}$ \\
\hline Max. & $72.79 \times 10^{3}$ & $180.44 \times 10^{3}$ & $4.78 \times 10^{6}$ \\
\hline Min. & 0 & 0 & 0 \\
\hline \multicolumn{4}{|c|}{ Total phytoplankton (\%) } \\
\hline \multicolumn{4}{|c|}{ Microflagellates } \\
\hline Mean & 85.96 & 84.33 & 73.54 \\
\hline Max. & 99.85 & 99.92 & 99.87 \\
\hline Min. & 33.13 & 30.32 & 24.48 \\
\hline \multicolumn{4}{|c|}{ Cryptomonads } \\
\hline Mean & 10.69 & 9.70 & 16.50 \\
\hline Max. & 61.28 & 60.63 & 60.58 \\
\hline Min. & 0 & 0 & 0 \\
\hline \multicolumn{4}{|l|}{ Diatoms } \\
\hline Mean & 2.92 & 5.79 & 8.03 \\
\hline Max. & 90.41 & 68.94 & 70.12 \\
\hline Min. & 0.05 & 0.01 & 0 \\
\hline \multicolumn{4}{|c|}{ Dinoflagellates } \\
\hline Mean & 0.17 & 0.10 & 0.92 \\
\hline Max. & 8.22 & 1.72 & 18.27 \\
\hline Min. & 0 & 0 & 0 \\
\hline \multicolumn{4}{|l|}{ Other } \\
\hline Mean & 0.05 & 0.07 & 1.01 \\
\hline Max. & 2.40 & 3.88 & 54.55 \\
\hline Min. & 0 & 0 & 0 \\
\hline
\end{tabular}

\section{Salinity}

Salinity (data not shown) was almost uniformly $30 \%$ throughout the study at virtually all times (range $=26$ to $31 \%$ ). The only times when salinities were low were at $\operatorname{Stn} 8$ in the enclosed inner harbor of New Bedford, immediately after or during heavy rain (for an example, see Borkman et al. 1993). 


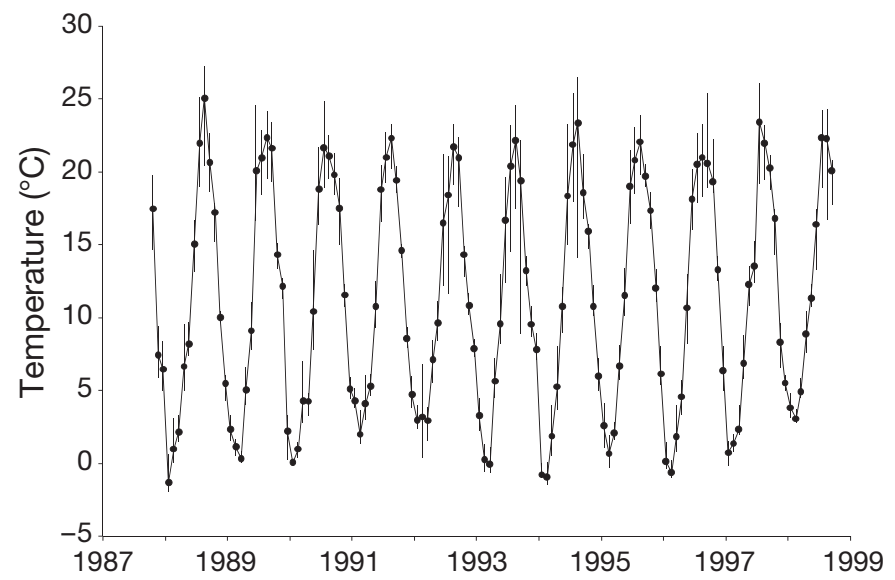

Fig. 2. Mean temperatures $\left({ }^{\circ} \mathrm{C}\right)$. Data points are means, and vertical lines are ranges for surface, mid-depth and bottom samples at all 8 stations on a given sampling date during Cruises 1 to 141, October 1987 to September 1998

\section{Light penetration}

Buzzards Bay was usually visibly green at many stations, so Secchi disk values were often low, but were also occasionally $>10 \mathrm{~m}$, especially at the mid-bay stations (range for all stations $=0.8$ to $12.0 \mathrm{~m}$, mean $=3.9 \mathrm{~m}$, Fig. 3). However, at Stn 7 over the New Bedford sewage outfall, water color was usually brown due to fine particles of sludge. Secchi disk values at this station were 0.8 to $6.0 \mathrm{~m}$, with a mean of only $2.3 \mathrm{~m},<60 \%$ that of the rest of the bay. After the New Bedford sewage treatment facility converted from primary-treated effluent to secondary-treatment in September 1996, there was a marked increase in Secchi disk values from usually $<2 \mathrm{~m}$ to 2-6 m (see middle panel of Fig. 3).

Despite the generally low Secchi disk values, since Buzzards Bay is shallow (generally $<10 \mathrm{~m}$ bottom depth) most of the water column is in the euphotic zone, with illumination $>1 \%$ of surface levels most of the time (mean of $92.61 \%$ of the water column euphotic, range for all stations $=34.3$ to $100 \%$ ). Together with the high nutrient levels, this illuminated water column allows for substantial phytoplankton growth throughout most of the year, explaining the 'green' water color, and hence the low Secchi disk values. The only cases where the bottom was not euphotic were due to low sun angle in winter at several stations, or frequently throughout the year at Stn 7 over the sewage outfall due to particles of sludge from the outfall (Turner \& Borkman 1993).

\section{Chlorophyll a}

Surface chl a levels were comparatively high (mean for all stations $=6.19$, range $=0.10$ to $64.66 \mu \mathrm{g} \mathrm{l}^{-1}$ ) and relatively uniform throughout the bay on a given day, except for high summer concentrations at Stns 7 (sewage outfall) and 8 (inner harbor) (Fig. 4). The declines in chlorophyll levels at Stn 7 over the sewage outfall, and particularly at Stn 8 in the inner harbor of New Bedford after October 1996, presumably reflect improved sewage treatment. There was no consistent pattern of recurrent seasonal blooms, such as a spring bloom. Rather, blooms measured as sharp increases in chlorophyll occurred sporadically in all seasons (Fig. 4).

\section{Nutrients}

Nutrient values over all depths are presented in Fig. 5 (ammonium), Fig. 6 (nitrate + nitrite), Fig. 7 (phosphate) and Fig. 8 (silicate). Plots of temporal distributions of nutrients present mean values (data points), with vertical bars denoting ranges between surface, mid-depth and bottom values. In the upper panel of each figure, data for Stns 1 to 6 were pooled, with means calculated from all stations and depths on a given day. In the middle and bottom panels of each figure, data for Stns 7 and 8, respectively, are presented, with data points representing means, and vertical bars the range of values for all 3 depths at that station on a given day. In many cases in all of the nutrient plots, ranges were so low that vertical bars in nutrient plots were smaller than the sizes of data points representing means.

Due to the shallow well-mixed water column, nutrient levels at all stations except Stn 7 were generally similar over the 3 depths sampled. However, due to the surface plume of low-salinity effluent from the New Bedford sewage outfall, levels of ammonium and phosphate at Stn 7 were usually much higher at the surface than at other depths at the same station, or at any depth in the rest of the bay (note different scales on $y$-axis for different stations). This was less apparent for distributions of nitrate + nitrite and silicate. Such a pattern would be expected in an area affected by sewage effluent, since ammonium is a degradation product of urea, and high phosphates in sewage reflect detergents in wastewater (Ryther \& Dunstan 1971). High mean levels of ammonium and phosphate were also found at Stn 8 in the New Bedford inner harbor, but levels were generally similar throughout the water column. This probably reflects shallow depth $(8 \mathrm{~m})$, runoff from the Acushnet River which empties into the northern end of the harbor, prolonged residence times of water retained behind the hurricane dike, and combined sewage overflows which enter the harbor from numerous locations around its periphery. 



Fig. 3. Secchi disk depths at Stns 1 to 6, Stn 7, and Stn 8 during Cruises 1 to 141, October 1987 to September 1998. Data points for Stns 1 to 6 are means, and vertical lines are ranges.

Data points for Stns 7 and 8 are single determinations

Fig. 5. Ammonium $\left(\mathrm{NH}_{4}\right)$ concentrations at Stns 1 to 6 , Stn 7 , and Stn 8 during Cruises 1 to 141, October 1987 to September 1998. Data points are means for a given sampling date for all 3 depths (surface, mid-depth and bottom), and vertical lines are ranges


Fig. 4. Chlorophyll $a+$ phaeopigment concentrations at Stns 1 to 6, Stn 7, and Stn 8 during Cruises 1 to 141, October 1987 to September 1998. Data points are means for a given sampling date for all 3 depths (surface, mid-depth and bottom) and vertical lines are ranges
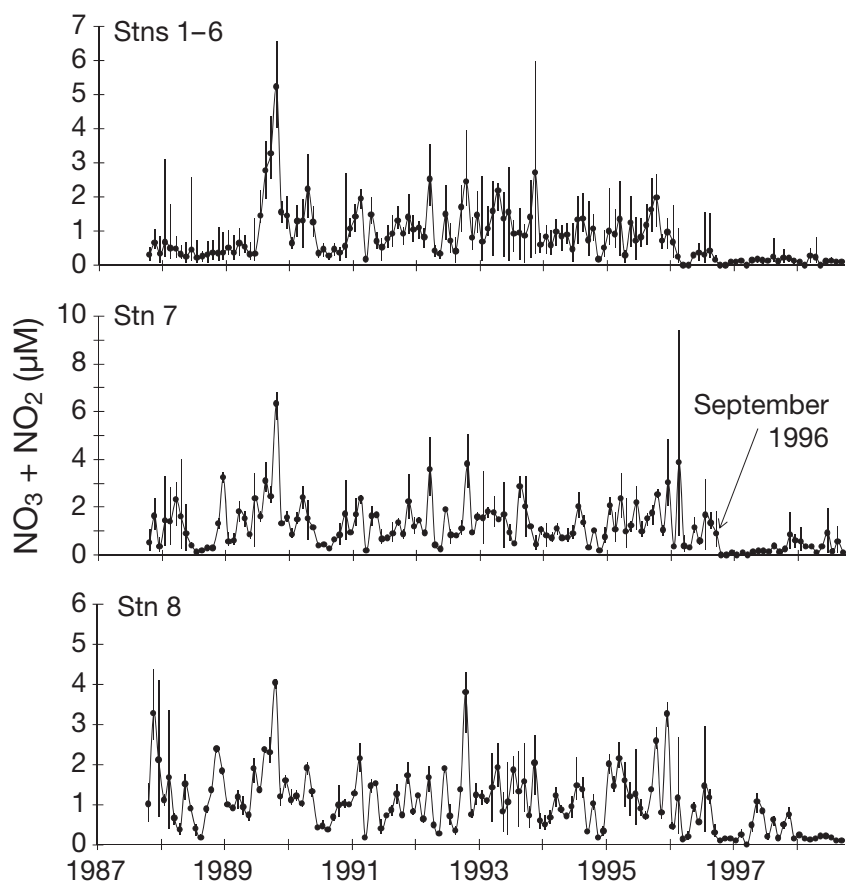

Fig. 6. Nitrate + nitrite $\left(\mathrm{NO}_{3}+\mathrm{NO}_{2}\right)$ concentrations at $\mathrm{Stns} 1$ to 6, Stn 7, and Stn 8 during Cruises 1 to 141, October 1987 to September 1998. Data points are means for a given sampling date for all 3 depths (surface, mid-depth and bottom), and vertical lines are ranges 



Fig. 7. Phosphate $\left(\mathrm{PO}_{4}\right)$ concentrations at Stns 1 to $6, \operatorname{Stn} 7$, and Stn 8 during Cruises 1 to 141, October 1987 to September 1998. Data points are means for a given sampling date for all 3 depths (surface, mid-depth and bottom), and vertical lines are ranges
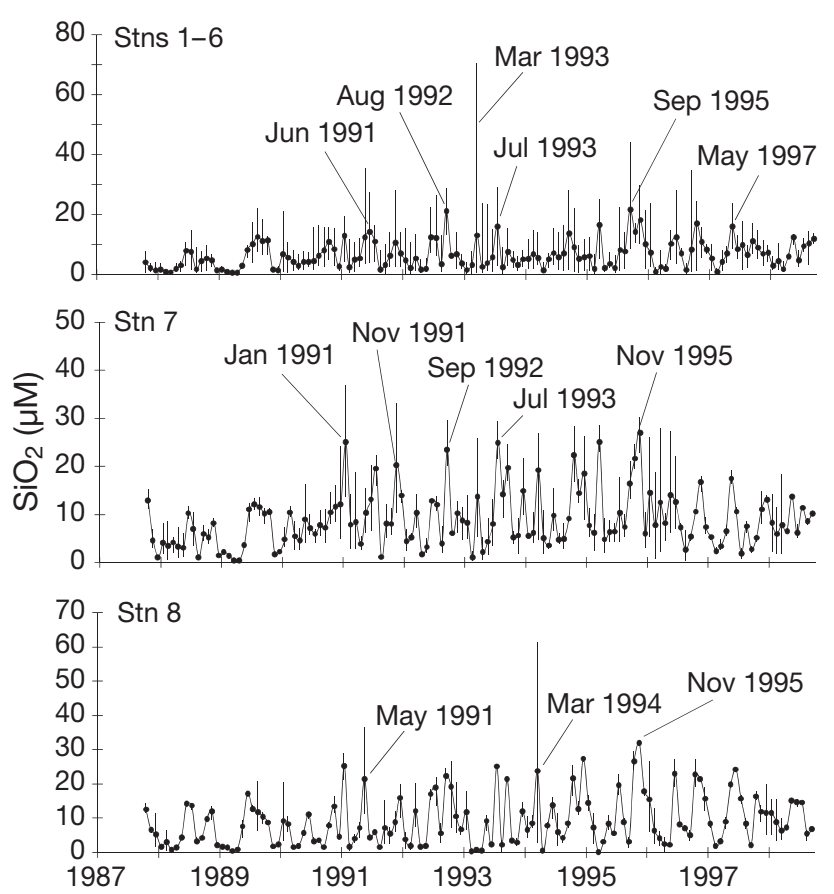

Fig. 8. Silicate $\left(\mathrm{SiO}_{2}\right)$ concentrations at Stns 1 to 6 , Stn 7, and Stn 8 during Cruises 1 to 141, October 1987 to September 1998. Data points are means for a given sampling date for all 3 depths (surface, mid-depth and bottom), and vertical lines are ranges

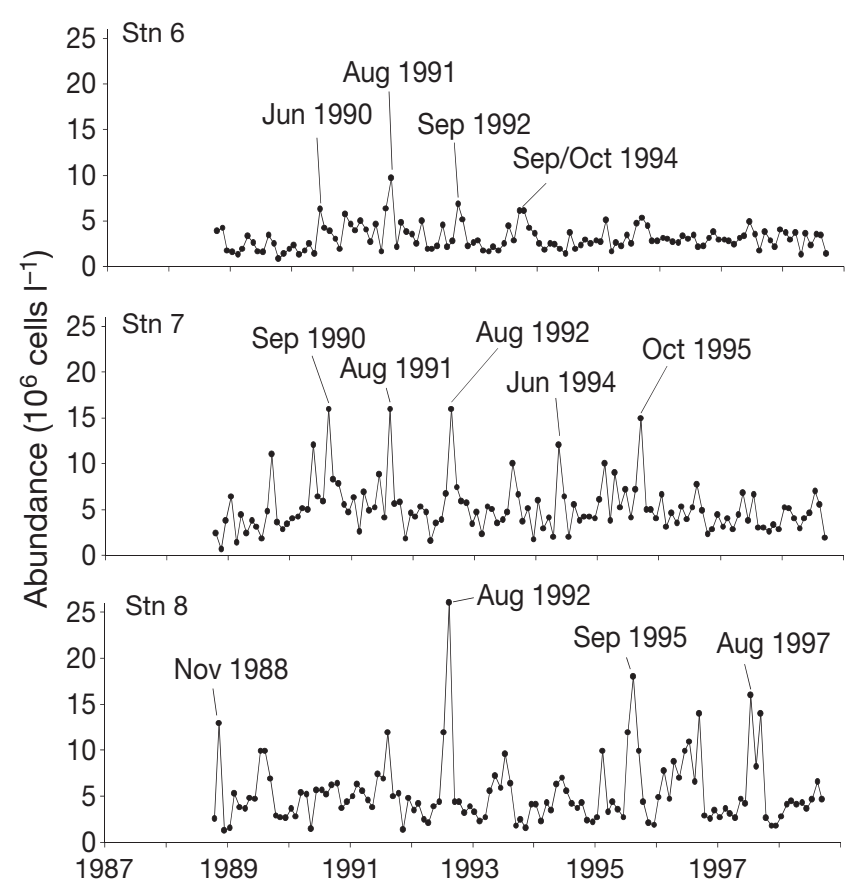

Fig. 9. Surface abundance of total phytoplankton at Stns 6 , 7 and 8 from Cruise 18 (October 1988) through Cruise 141 (September 1998). Data points are single determinations

Ammonium levels were highest at Stn 7, with much lower and comparatively uniform levels elsewhere (Fig. 5), and ammonium was the major form of inorganic nitrogen available throughout the bay. As a percentage of total dissolved inorganic nitrogen (DIN = $\mathrm{NH}_{4}{ }^{+}+\mathrm{NO}_{3}^{-}+\mathrm{NO}_{2}^{-}$), ammonium comprised up to $>99 \%$, with a mean for all stations of $76.08 \%$ (Table 1 ), likely reflecting the shallow water column and resuspension of ammonium regenerated in the benthos. Ammonium values were typically higher during the warmer months, particularly at Stn 7. Ammonium levels at the sewage outfall (Stn 7) were also somewhat lower after September 1996, when the sewage treatment facility converted to secondary treatment. Peak levels of ammonium after then were never as high as those recorded prior to conversion to secondary treatment (see middle panel of Fig. 5).

Levels of nitrate + nitrite (Fig. 6) were different from those of ammonium. Nitrate fluctuations over time were much more moderate than those of ammonium (compare $y$-axes in Fig. 6 to those of Fig. 5), since ammonium levels were heavily biased by the sewage outfall. There was also considerable interannual variability in nitrate + nitrite distributions within given months, as well as considerable variability between depths at the same stations at the same time (note height of range bars in plots in Fig. 6). 
Phosphate levels (Fig. 7) were higher during the warmer months at Stn 7 in most years. Otherwise, phosphate levels were comparatively uniform and low $($ mean $=1.04$, range $=0.00$ to $8.86 \mu \mathrm{M})$ throughout the rest of the bay, compared to a mean of $2.58 \mu \mathrm{M}$, range $=0.08$ to $27.02 \mu \mathrm{M}$, at Stn 7 . The high phosphate levels at Stn 7 are likely a reflection of sewage effluent, in that the mean concentration at this station was nearly 3 times that for the rest of the bay.

There were generally bay-wide (Stns 1 to 6) increases in silicate levels during the warmer months, followed by declines in fall, during most years (Fig. 8). Silicate levels at Stns 7 and 8 were more sporadic, with peak levels in cold as well as warm months.

\section{Phytoplankton}

In the only comprehensive phytoplankton study from Buzzards Bay prior to this one, Borkman (1994) presented nutrient, chlorophyll and hydrographic data for all 3 depths for all 8 stations, and phytoplankton data


Fig. 10. Comparative surface abundance of microflagellates, dinoflagellates, diatoms and cryptomonads at Stns 6 to 8 from Cruise 18 (October 1988) through Cruise 141 (September 1998). Histograms are single determinations 




Fig. 11. Surface abundance of microflagellates at Stns 6, 7 and 8 from Cruise 18 (October 1988) through Cruise 141 (September 1998). Data points are single determinations

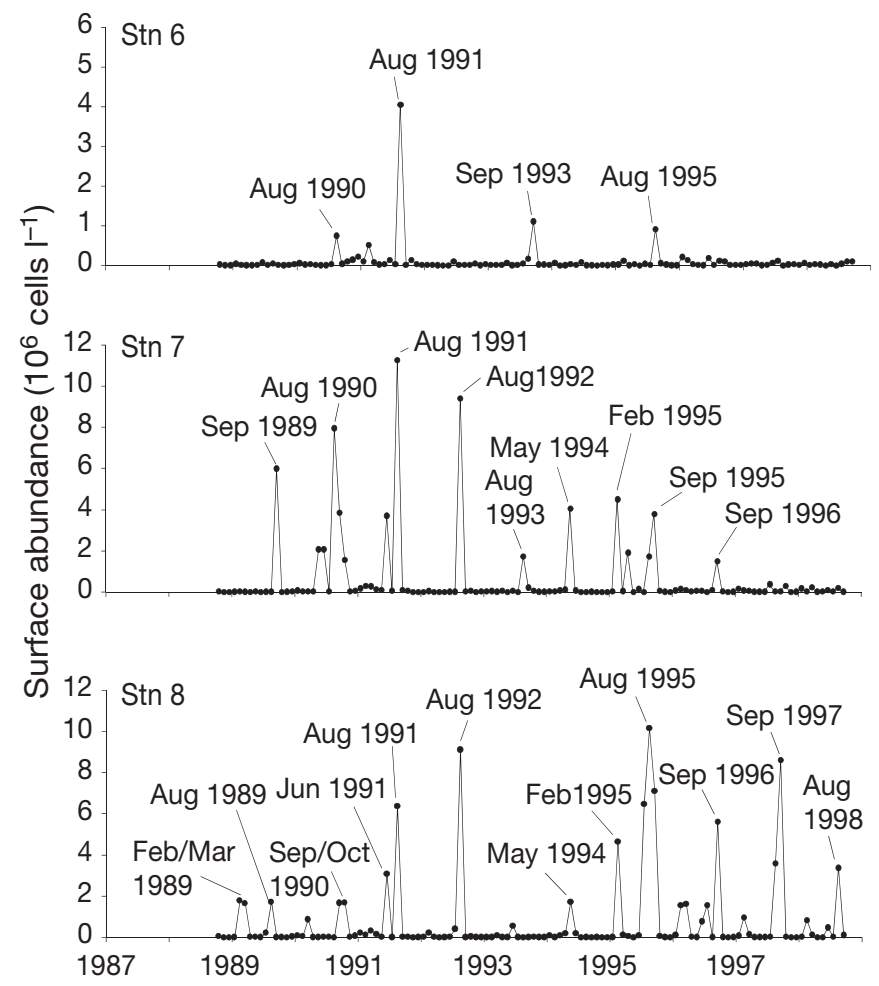

Fig. 13. Surface abundance of diatoms at Stns 6, 7 and 8 from Cruise 18 (October 1988) through Cruise 141 (September 1998). Data points are single determinations



Fig. 14. Surface abundance of Skeletonema spp. at Stns 6, 7 and 8 from Cruise 18 (October 1988) through Cruise 141

(September 1998). Data points are single determinations

Fig. 12. Surface abundance of cryptomonads at Stns 6, 7 and 8 from Cruise 18 (October 1988) through Cruise 141 (September 1998). Data points are single determinations 
for surface samples from all 8 stations plus data for all 3 depths (Stns 6, 7, and 8) for Cruises 1 to 17 (October 1987 to September 1988). Because Borkman's (1994) thesis results have never been published, and because his results set the stage for our subsequent phytoplankton analyses, his 1987-88 results are briefly summarized below, followed by a summary of phytoplankton abundance and percentage composition patterns for October 1988 to September 1998 for surface samples from Stns 6, 7 and 8, presented in Table 2, and Figs. 9 to 19 .

\section{Borkman's (1994) phytoplankton results for Cruises 1 to 17 (October 1987 to September 1988)}

Borkman (1994) found that nutrients were distributed homogeneously with depth at most stations. The major exception was at Stn 7, the New Bedford sewage outfall, where all nutrients were at significantly higher concentrations at the surface than at mid-depth and near-bottom. Phytoplankton abundance was also usually higher at Stn 7 (sewage outfall) and Stn 8 (inner harbor of New Bedford) than at the other 6 stations away from New Bedford. Nutrients at these 6 stations were relatively unaffected by anthropogenic additions, and were typical of other New England estuaries. Ammonium levels were highest in the summer, whereas nitrate + nitrite levels were highest in winter prior to a period of increased diatom abundance in the late winter and early spring. Phosphate levels varied little over the year. Silicate levels were significantly higher in June and July than during the rest of the year, and June and July were periods when microflagellates and dinoflagellates were in much higher concentrations than diatoms. The period of increased silicate levels in June and July preceded a major diatom bloom of Skeletonema spp. in August and early September 1988. This

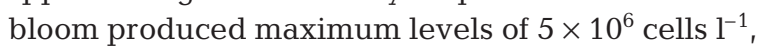
and it was the major bloom event of the 1987-88 year. By comparison, a winter-spring diatom bloom was not recorded for Buzzards Bay in 1988. Throughout the winter and early spring a mixed diatom community, persisted at abundance levels of $<1 \times 10^{6}$ cells $1^{-1}$. This assemblage was dominated by several species of Chaetoceros. In May, microflagellates and dinoflagellates began to comprise increasingly large proportions of the phytoplakton community. Microflagellates reached their maximum abundance $\left(1.5 \times 10^{6}\right.$ cells $\left.^{-1}\right)$ in late July prior to the Skeletonema spp. bloom in August. Dinoflagellates reached their maximum abundance $(6.9 \times$ $10^{5}$ cells $1^{-1}$ ) in May at Stn 8 in New Bedford Harbor when the dinoflagellate Heterocapsa triquetra bloomed. The highest concentrations of dinoflagellates were consistently found at Stns 7 and 8 in New Bedford Harbor.

Similar to nutrient and chl a distributions, Borkman (1994) found that phytoplankton abundance levels in 1987-88 were usually not significantly different between different depths at most stations on a given day. This was as expected, since Buzzards Bay is shallow and well-mixed throughout the year. However, there were occasional differences in vertical patterns of phytoplankton abundance at Stn 7, with higher levels at the surface in the lower salinity lens caused by freshwater discharged from the sewage outfall. Overall phytoplankton abundance levels ranged from $6.19 \times$ $10^{4}$ cells $1^{-1}$ (Stn 6, bottom, December 1987) to $4.98 \times$ $10^{6}$ cells $^{-1}$ (Stn 3, surface, September 1988), with a mean of $5.4 \times 10^{5}$ cells $1^{-1}$.

Borkman (1994) found that diatoms dominated the phytoplankton community in 1987-88, comprising 2.4 to $99.1 \%$ of the cells counted (mean $=67.7 \%$ ). Microflagellates, most abundant in the summer months, were second in overall abundance, with a mean of $25.3 \%$ (range $=0$ to $93.4 \%$ ) of the cells counted. Dinoflagellates, while occasionally abundant in the warmer months, were usually a minor component of the phytoplankton abundance, with a mean of $6.9 \%$ (range $=0$

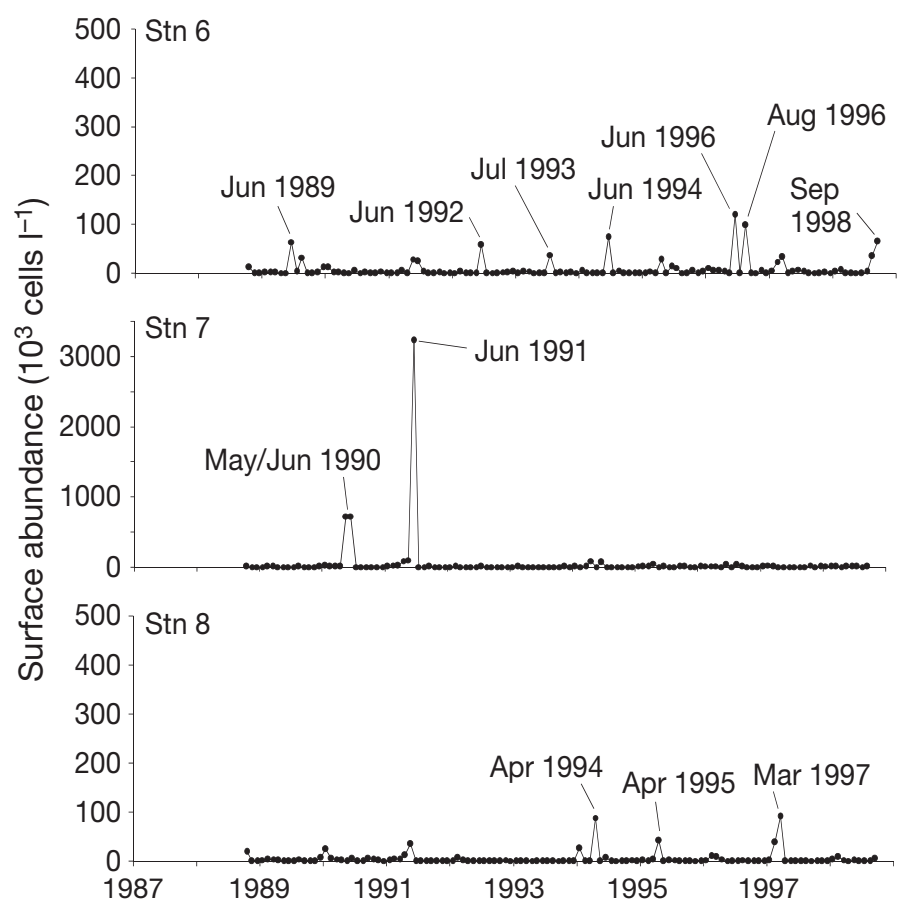

Fig. 15. Surface abundance of species presently or formerly known as members of the diatom genus Rhizosolenia at Stns 6, 7 and 8 from Cruise 18 (October 1988) through Cruise 141 (September 1998). Data points are single determinations. Note different scale of abundance for $\operatorname{Stn} 7$ 


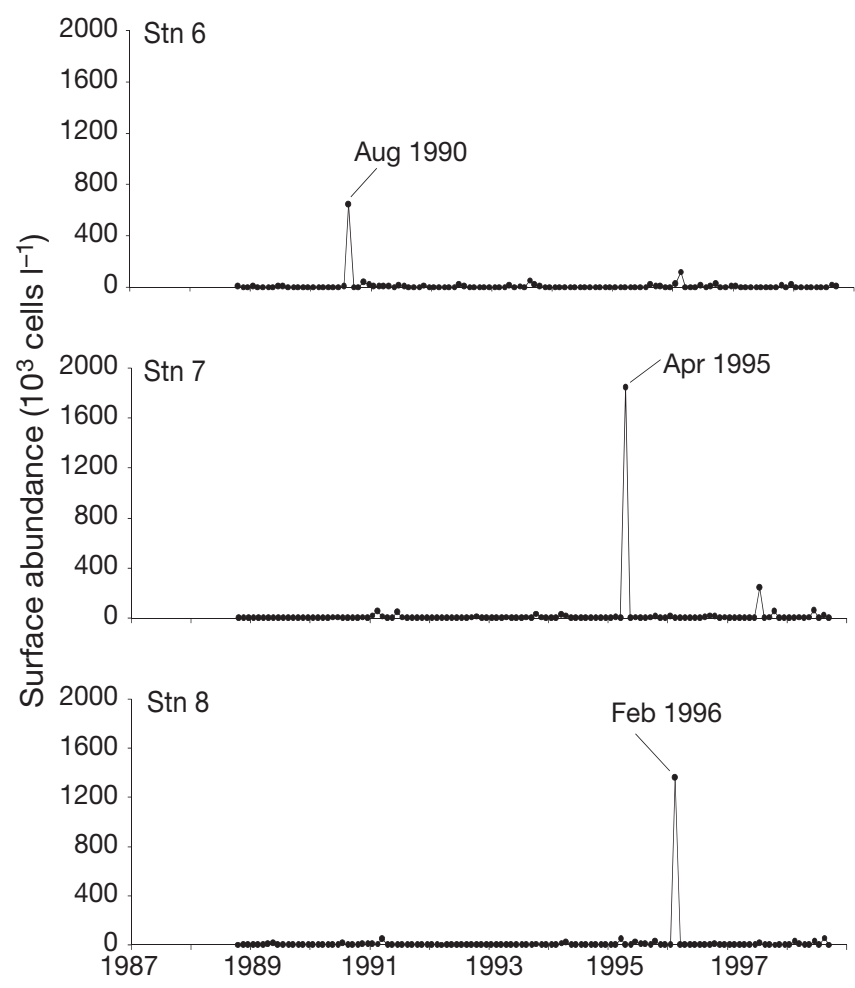

Fig. 16. Surface abundance of Chaetoceros spp. at Stns 6, 7 and 8 from Cruise 18 (October 1988) through Cruise 141 (September 1998). Data points are single determinations



Fig. 17. Surface abundance of Thalassiosira spp. at Stns 6, 7 and 8 from Cruise 18 (October 1988) through Cruise 141 (September 1998). Data points are single determinations



Fig. 18. Surface abundance of Pseudo-nitzschia spp. at Stns 6, 7 and 8 from Cruise 18 (October 1988) through Cruise 141 (September 1998). Data points are single determinations

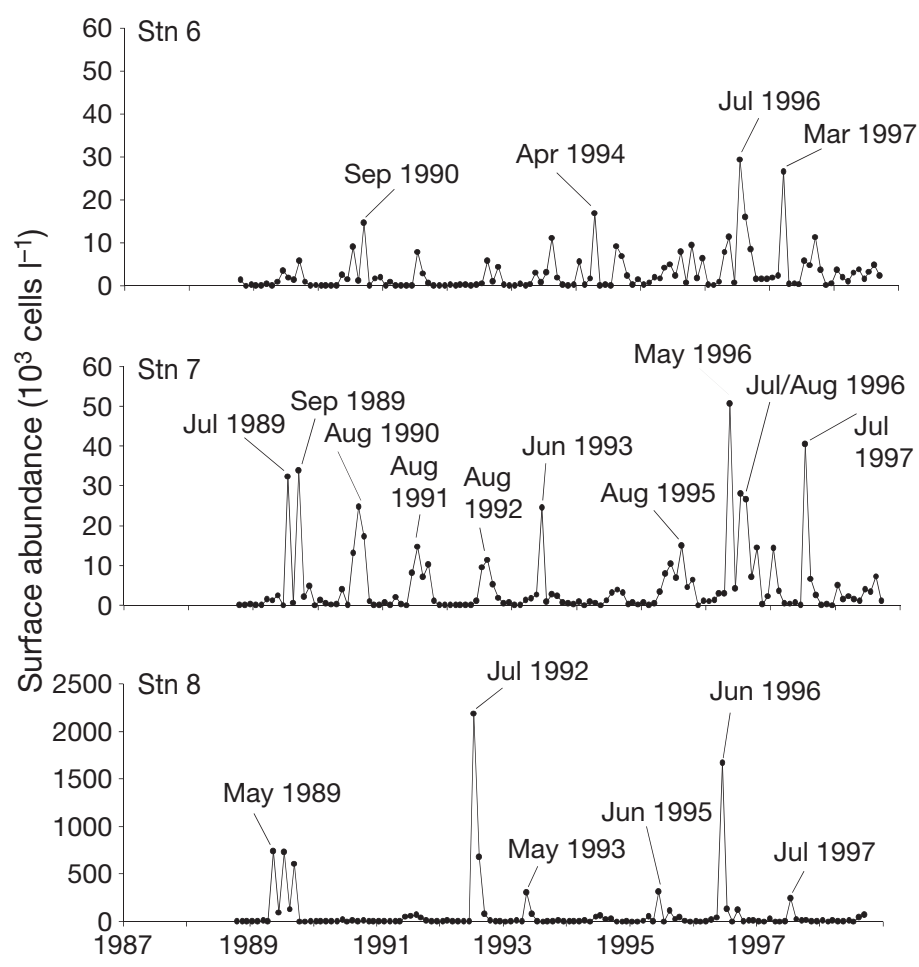

Fig. 19. Surface abundance of dinoflagellates at Stns 6, 7 and 8 from Cruise 18 (October 1988) through Cruise 141 (September 1998). Data points are single determinations 
to $57.2 \%$ ) of cells counted. The annual pattern of phytoplankton abundance in 1987-88 was dominated by a single late-summer bloom that resulted in significantly higher surface concentrations of phytoplankton at all 8 stations in August 1988. This bloom of Skeletonema spp. was present at all 8 stations from late July through early September.

Several HAB phytoplankton taxa were recorded in 1987-88. Borkman (1994) recorded decaying colonies of the prymnesiophyte Phaeocystis pouchetii in early June in the Cape Cod Canal and at the New Bedford sewage outfall. The raphidophyceaen Heterosigma akashiwo, synonymous with Olisthodiscus luteus and/or Heterosigma carterae (Heywood 1989) was recorded at Stns 3, 4, 5 and 8 at low abundances at various times during the warmer months. Because of the small numbers of cells recorded, Borkman (1994) noted their presence only, since the error in abundance estimates for these cells would approach $100 \%$. In addition to taxa noted by Borkman (1994), a concurrently collected set of samples of microplankton $>20 \mu \mathrm{m}$ in longest dimension (Pierce \& Turner 1994a) revealed the presence of the toxic dinoflagellate Alexandrium fundyense (listed as $A$. tamarense) at various stations throughout Buzzards Bay from June through October 1988. A. fundyense was most frequently recorded for locations in northeastern Buzzards Bay, where it likely entered from the east via the Cape Cod Canal. Abundance levels of $A$. fundyense in these locations were typically 10 to 100 cells $1^{-1}$, but the one time it was recorded for Stn 8 in New Bedford Harbor (July 1988), it exhibited $3 \times 10^{3}$ cells $\mathbf{l}^{-1}$.

Borkman (1994) attempted to relate fluctuations in the abundance and composition of the phytoplankton community (1987-88) to environmental parameters. Correlation analyses of the 29 most common phytoplankton taxa and environmental factors (temperature, salinity, nitrate + nitrite, precipitation, light attenuation, ammonium, phosphate, silicate) revealed that temperature was the most prominent environmental parameter in the observed seasonal patterns of phytoplankton abundance and composition in 1987-88. Borkman (1994) concluded that temperature may act as a master variable controlling or co-varying with many other processes that affect phytoplankton distribution and abundance.

\section{Phytoplankton patterns for Cruises 18 to 141, October 1988 to September 1998}

Total phytoplankton abundance (Cruises 18 to 141, October 1988 to September 1998, at Stns 6, 7, and 8) averaged approximately 3.0 to $5.4 \times 10^{6}$ cells $\mathrm{l}^{-1}$, with maximum values of $26 \times 10^{6}$ cells $\mathrm{l}^{-1}$. In terms of mean, maximum and minimum phytoplankton abundance, there was usually a progression of increasing phytoplankton abundance from the middle of the bay (Stn 6) to the sewage outfall (Stn 7) to the inner harbor (Stn 8). There were no consistent seasonal trends in abundance of total phytoplankton (Fig. 9). Rather, there was considerable variability in total abundance with season in different years, as well as from station to station on a given cruise. Contrary to the 'textbook' pattern of a pronounced spring bloom in temperate coastal waters, maximum levels of phytoplankton cell abundance were found in summer and fall (Fig. 9). This pattern also did not correspond to peaks in chl a (Fig. 4) which often occurred in February and March.

Phytoplankton abundance (1988 to 1998) was overwhelmingly dominated by microflagellates, comprising overall station means of approximately 73 to $86 \%$ of total cells counted (Fig. 10). The designation 'microflagellates' was used for spherical cells $<5 \mu \mathrm{m}$, and mostly $<2 \mu \mathrm{m}$ in diameter. Microflagellates were generally most abundant during warmer months (Fig. 11), although they were a major component of the phytoplankton year-round. Another consistently abundant category of cells was 'cryptomonads,' comprising means of 9.7 to $16.5 \%$ of total cells. This category included the genus Teleaulax, and other unidentified teardropshaped cells. Cryptomonads were also most abundant during warmer months (Fig. 12).

Although scores of diatom taxa were recorded (Appendix 2), diatoms comprised overall station means of only 2.9 to $8.0 \%$ numerically of total phytoplankton cell abundance (Table 2). However, during certain blooms (Fig. 13), diatoms occasionally comprised up to $90 \%$ of cells at a given station on a given day (Fig. 10). With the exception of minor diatom blooms at Stns 7 and 8 in February-March 1989, May 1994 and February 1995 (Fig. 13), these diatom blooms were all in summer and fall, mainly in August and September.

The main diatom taxon that exhibited major blooms was Skeletonema spp. (Fig. 14), usually in late summer or early fall. Peak abundances of Skeletonema spp. usually corresponded to those of total diatoms (Fig. 13), indicating that most diatom blooms were Skeletonema spp. blooms. Although this taxon was initially identified as S. costatum, recent studies (Sarno et al. 2005, 2007, Zingone et al. 2005) have shown that many records attributed to this species likely encompass different members of a species complex within this genus. On occasion, blooms of Skeletonema spp. reached 10

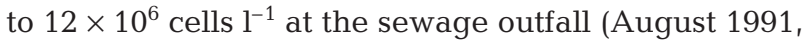
Stn 7) and in the inner harbor of New Bedford (August 1992 and 1995, Stn 8). Skeletonema spp. also form major blooms in Narragansett Bay which exhibit considerable interannual variability in timing, occurring primarily in winter-spring or summer-fall (Karentz \& Smayda 1984, 1998, Smayda 1998, Borkman 2002). 
Other diatom genera exhibited blooms which were highly variable in time and space. Included were species currently or historically regarded as members of the genus Rhizosolenia (see synonyms and basionyms of Rhizosolenia spp. listed in Appendix 2) (Fig. 15). Of particular note were blooms exceeding $500 \times 10^{3}$ cells $1^{-1}$ at Stn 7 , which were not matched elsewhere in the bay. These included blooms of the species Dactyliosolen fragilissimus (formerly known as $R$. fragilissima) in May-June 1990, and Guinardia delicatula (formerly known as $R$. delicatula) in June 1991. There were also blooms of various species of the genera Chaetoceros (Fig. 16) in August 1990 at Stn 6, in April 1995 and July 1997 at Stn 7, and in February 1996 at Stn 8. Various species of Thalassiosira (Fig. 17) bloomed frequently at Stn 8 in the inner harbor of New Bedford in February and March of both 1989 and 1990, in June of both 1991 and 1993, in March, July, and September 1996, and in September 1997. These blooms often included several species of the genus Thalassiosira (Appendix 2), which bloomed concurrently at Stn 8, but did not bloom elsewhere in the bay on the same days (Fig. 17).

The primary diatom genus in Buzzards Bay that could be considered 'harmful' is Pseudo-nitzschia. P. multiseries has produced toxic blooms elsewhere in North America with occasional fatal intoxication of humans or seabirds after ingestion of shellfish or fish containing the neurotoxin domoic acid, produced by this diatom (Bates et al. 1998).

There were frequent blooms of Pseudo-nitzschia spp. during the present study (Fig. 18). These blooms occurred in various seasons in different years, at different stations. At this point we do not know if any of these blooms were of toxic $P$. multiseries because requisite ultrastructural features were not identified by scanning electron microscopy examination. Nonetheless, Pseudo-nitzschia spp. were repeatedly recorded in the present study at abundances of 20 to $60 \times$ $10^{3}$ cells $\mathrm{l}^{-1}$. While these abundances are well below the Canadian threshold of $10^{5}$ cells $\mathrm{l}^{-1}$, which prompts increased vigilance for domoic acid in shellfish, it is apparent that phytoplankton monitoring for Pseudonitzschia spp. should probably continue in Buzzards Bay.

Dinoflagellates were rarely abundant in the present study, comprising overall station means of $<1 \%$ of total cell numbers. However, there were numerous sporadic blooms (Figs. 10 \& 19), usually of mixed species. Maximum dinoflagellate percentage composition occasionally reached as much as $18 \%$ of total cells, usually at Stn 8 in the inner harbor of New Bedford. Although numerous dinoflagellate taxa were recorded, the primary one of societal interest was Alexandrium fundyense, which can produce PSP toxins. Although A. fundyense was sporadically recorded throughout the survey, abundances were usually low (100s of cells $\mathrm{l}^{-1}$ ) outside the inner harbor of New Bedford. However, occurrences of this species at Stn 8 within the inner harbor were more frequent than outside it, and abundances were occasionally in the range of thousands, rather than hundreds of cells per liter. This confirms the repeatability of summer blooms of $A$. fundyense, such as that initially recorded for summer 1988 (listed by Borkman et al. 1993 as $A$. tamarense). Again, this suggests that phytoplankton monitoring for this and other potentially harmful phytoplankton species in Buzzards Bay should be continued.

\section{Long-term trend analysis}

We tested for linear trends over time for most measured variables, for all combinations of stations and depths. These variables included chlorophyll, all nutrients, and surface temperature. All but two of these variables (chlorophyll and nitrate + nitrite) did not exhibit significant patterns of long-term change at all station-all depth combinations over time.

Chl a had significant linear declines of 0.3 to $0.5 \mu \mathrm{g}$ $\mathrm{l}^{-1} \mathrm{yr}^{-1}$ at Stns 1 to 6 , a decline of $0.7 \mu \mathrm{g} \mathrm{l}^{-1} \mathrm{yr}^{-1}$ at $\operatorname{Stn} 7$ and greatest declines of 1.4 to $2.1 \mu \mathrm{g} \mathrm{l}^{-1} \mathrm{yr}^{-1}$ at Stn 8 (regression equations for all stations-all depths in Table 3, and data for Stns 6, 7, and 8 in Figs. 20 to 22, respectively). Expressed as percentages, chlorophyll levels in the late 1990s had declined to 20-40\% (depending on station) of the chlorophyll concentrations observed in the late 1980s. Chlorophyll concentrations declined gradually over the 1987 to 1998 period, with no abrupt declines in chlorophyll concentrations apparent in any given year.

Nitrate + nitrite concentrations showed overall significant linear declines consistently at all stations and depths during 1987 to 1998 (Fig. 23). However, unlike chl $a$, the nitrate declines appeared to be largely due to drastic declines during 1996 and especially 1997. Mean annual nitrate levels during 1996-97 (mean for all stations and depths $=0.25 \mu \mathrm{M}$ ) were $25 \%$ of the nitrate concentrations observed during 1987 to 1995 $($ mean $=1.07 \mu \mathrm{M})$. These declines in nitrate came after conversion of the New Bedford sewage treatment plant to secondary treatment in September 1996.

No variables other than chl $a$ and nitrate had consistent linear trends at all stations and depths. However, several variables had consistent trends at subgroups of stations. For example, phosphate concentrations increased by 50 to $70 \%$ at Stns 7 and 8 during 1987 to 1998. Ammonium had significant linear declining trends at Stns 6 and 7 at the surface only, likely in response to secondary sewage treatment implemented 



Fig. 20. Trend in chlorophyll a concentration at Stn 6 surface, mid-depth and bottom during 1987 to 1998. Significant regression lines are shown; regression equations are presented in Table 3



Fig. 21. Trend in chlorophyll a concentration at Stn 7 surface, mid-depth and bottom during 1987 to 1998. Significant regression lines are shown; regression equations are presented in Table 3
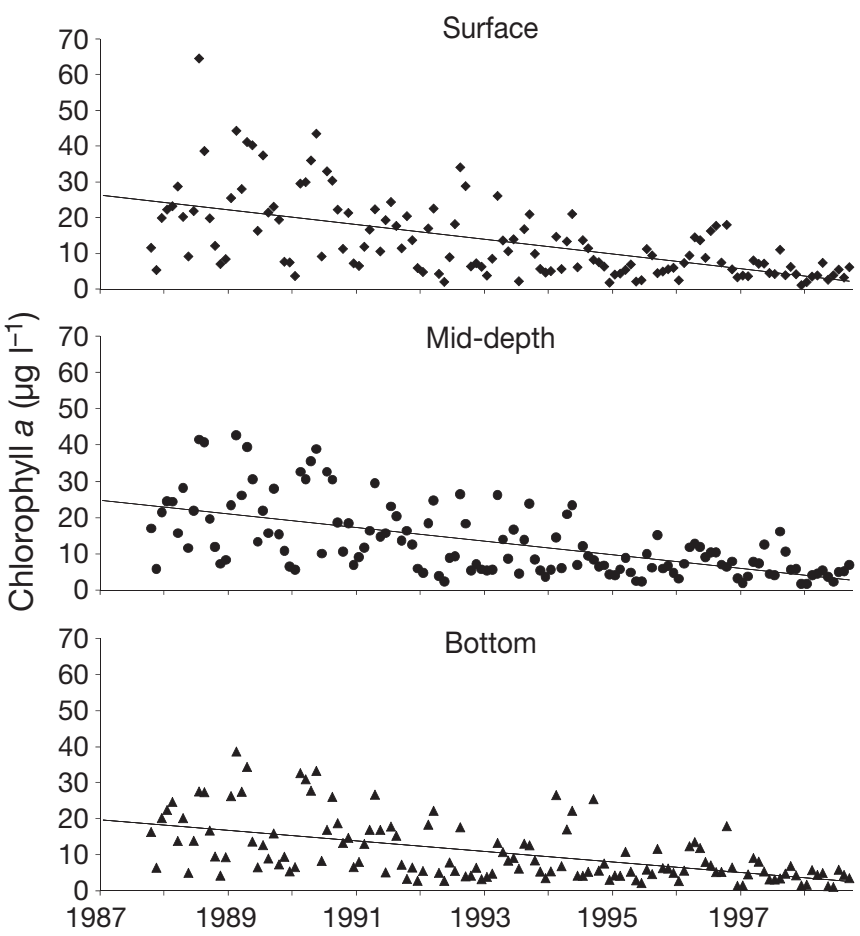

Fig. 22. Trends in chlorophyll a concentration at Stn 8 surface, mid-depth and bottom during 1987 to 1998. Significant regression lines are shown; regression equations are presented in Table 3

Table 3. Linear regression trends of chl a over time (all stations-all depths) for Cruises 1 to 141. $p<0.0001$ in all cases

\begin{tabular}{|c|c|c|c|}
\hline Stn & Depth & Eq. & $\mathrm{r}^{2}$ \\
\hline Stn 1 & $\begin{array}{l}\text { Surface } \\
\text { Mid-depth } \\
\text { Bottom }\end{array}$ & $\begin{array}{l}y=-0.032 x+7.260 \\
y=-0.033 x+7.314 \\
y=-0.028 x+7.405\end{array}$ & $\begin{array}{l}0.28 \\
0.30 \\
0.19\end{array}$ \\
\hline Stn 2 & $\begin{array}{l}\text { Surface } \\
\text { Mid-depth } \\
\text { Bottom }\end{array}$ & $\begin{array}{l}y=-0.030 x+6.715 \\
y=-0.028 x+6.709 \\
y=-0.029 x+6.726\end{array}$ & $\begin{array}{l}0.28 \\
0.22 \\
0.23\end{array}$ \\
\hline Stn 3 & $\begin{array}{l}\text { Surface } \\
\text { Mid-depth } \\
\text { Bottom }\end{array}$ & $\begin{array}{l}y=-0.033 x+7.260 \\
y=-0.033 x+7.281 \\
y=-0.037 x+8.006\end{array}$ & $\begin{array}{l}0.27 \\
0.28 \\
0.29\end{array}$ \\
\hline Stn 4 & $\begin{array}{l}\text { Surface } \\
\text { Mid-depth } \\
\text { Bottom }\end{array}$ & $\begin{array}{l}y=-0.029 x+7.077 \\
y=-0.030 x+7.309 \\
y=-0.033 x+7.827\end{array}$ & $\begin{array}{l}0.23 \\
0.23 \\
0.21\end{array}$ \\
\hline Stn 5 & $\begin{array}{l}\text { Surface } \\
\text { Mid-depth } \\
\text { Bottom }\end{array}$ & $\begin{array}{l}y=-0.040 x+7.838 \\
y=-0.043 x+8.187 \\
y=-0.046 x+8.987\end{array}$ & $\begin{array}{l}0.27 \\
0.30 \\
0.28\end{array}$ \\
\hline Stn 6 & $\begin{array}{l}\text { Surface } \\
\text { Mid-depth } \\
\text { Bottom }\end{array}$ & $\begin{array}{l}y=-0.039 x+7.945 \\
y=-0.042 x+8.525 \\
y=-0.046 x+8.992\end{array}$ & $\begin{array}{l}0.23 \\
0.25 \\
0.33\end{array}$ \\
\hline Stn 7 & $\begin{array}{l}\text { Surface } \\
\text { Mid-depth } \\
\text { Bottom }\end{array}$ & $\begin{array}{l}y=-0.051 x+10.17 \\
y=-0.053 x+10.63 \\
y=-0.055 x+10.53\end{array}$ & $\begin{array}{l}0.25 \\
0.33 \\
0.30\end{array}$ \\
\hline Stn 8 & $\begin{array}{l}\text { Surface } \\
\text { Mid-depth } \\
\text { Bottom }\end{array}$ & $\begin{array}{l}y=-0.172 x+26.30 \\
y=-0.157 x+24.80 \\
y=-0.122 x+19.84\end{array}$ & $\begin{array}{l}0.34 \\
0.37 \\
0.30\end{array}$ \\
\hline
\end{tabular}


Table 4. Regressions for May surface temperatures at Stns 3, 4, 5, and 6 for 1988 to 1998

\begin{tabular}{|cccc|}
\hline Stn & Eq. & $\mathrm{r}^{2}$ & $\mathrm{p}$-value \\
\hline 3 & $y=0.343 x-674.8$ & 0.62 & $<0.01$ \\
4 & $y=0.362 x-711.6$ & 0.69 & $<0.01$ \\
5 & $y=0.354 x-695.6$ & 0.77 & $<0.001$ \\
6 & $y=0.382 x-752.0$ & 0.78 & $<0.001$ \\
\hline
\end{tabular}

in 1996. Ammonium concentrations in the late 1990s declined to levels of only $32 \%$ (Stn 7) to 39\% (Stn 8) of the corresponding concentrations seen in the late 1980s. Secchi disk depths at Stn 7 had a strong linear increase of approximately $0.16 \mathrm{~m} \mathrm{yr}^{-1}$, increasing from $2.0 \mathrm{~m}$ prior to 1996 to $3.5 \mathrm{~m}$ during 1996 to 1998 , also likely in response to improved sewage treatment implemented in September 1996.

Mean annual surface temperatures ranged from $9.6^{\circ} \mathrm{C}(\operatorname{Stn} 2,1994)$ to $12.8^{\circ} \mathrm{C}(\operatorname{Stn} 8,1996)$, but had no significant linear trend at any station during 1987 to 1998. However, trends for mean annual temperatures may mask seasonally varying changes, so monthly mean temperatures were examined for linear trends during 1987 to 1998. Significant temperature trends were only detected in April, May and June. Significant warming (increasing temperature trend) was observed at some stations during April (Stns 6 and 8) and May (Stns 3, 4, 5, and 6). The slopes of all trend lines were between +0.27 and $+0.38^{\circ} \mathrm{C} \mathrm{yr}^{-1}$ (Table 4). During 1987 to 1998 a warming of $3^{\circ} \mathrm{C}$ occurred during May at the mid-bay stations (Stns 3, 4, 5, and 6; Fig. 24) perhaps indicative of an earlier onset of summer conditions in the Bay.

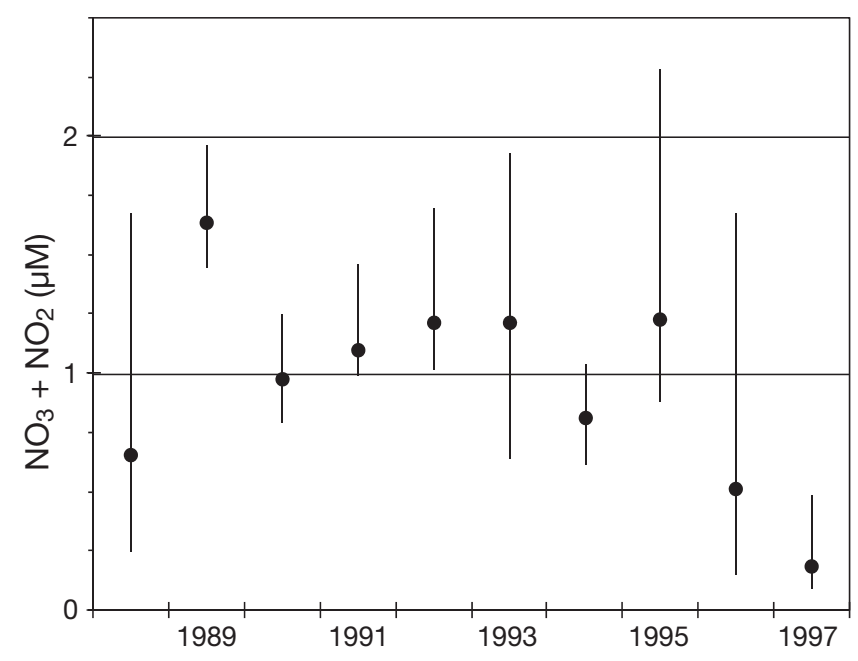

Fig. 23. Means and ranges of surface nitrate + nitrite $\left(\mathrm{NO}_{3}+\right.$ $\mathrm{NO}_{2}$ ) concentrations during 1988 to 1997 . Each data point represents the annual mean; vertical lines are ranges for surface depths at all stations and all cruises during the year

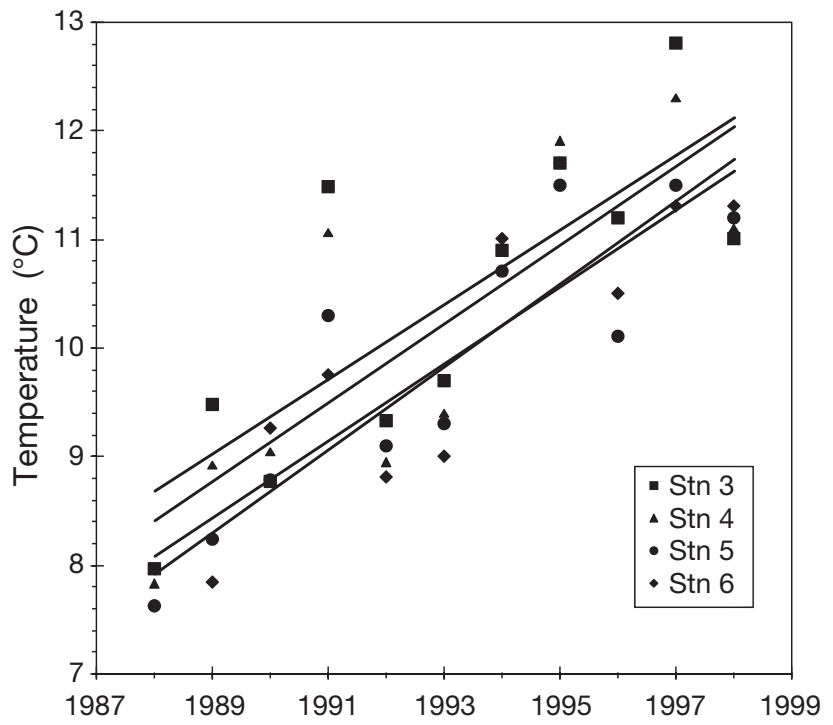

Fig. 24. May surface temperatures at Stns 3 to 6 during 1988 to 1998. Significant linear increases in May temperature of approximately $0.35^{\circ} \mathrm{C} \mathrm{yr}^{-1}$ were observed at these mid-bay

stations. Regression equations are presented in Table 4

\section{DISCUSSION}

Buzzards Bay is conducive to high phytoplankton abundance for several reasons. Due to shallow depths, the euphotic zone extends to the bottom for most of the year (Turner \& Borkman 1993). Thus, even though there is frequently complete vertical mixing of the water column, shallow bottom depth ensures that mixing is not below the critical depth (Sverdrup 1953). Mixing also facilitates bottom-up benthic-pelagic coupling. The sediments act as a nutrient pump injecting remineralized inorganic nutrients, particularly ammonium, to the water column. Thus, it is no surprise that ammonium averaged $76 \%$ of total DIN throughout the bay. Since nitrogen is usually the primary limiting nutrient in marine systems (Ryther \& Dunstan 1971), the nitrogen-replete conditions, coupled with adequate light, allowed abundant phytoplankton growth throughout the year in Buzzards Bay. In this respect, Buzzards Bay is similar to other nearby shallow well-mixed estuaries such as Narragansett (Smayda 1983, 1984) and Peconic Bay (Turner et al. 1983), but unlike deeper summerstratified coastal systems such as Long Island Sound (Conover 1956), Massachusetts and Cape Cod Bays (Townsend et al. 1991), and Georges Bank (Riley 1941). Because there is no seasonal pattern of stratification which increases during the spring, remains through the summer and breaks down in the fall, Buzzards Bay does not exhibit repeatable 'textbook' spring and fall blooms such as are found in some other temperate coastal waters. 
Buzzards Bay exhibits large seasonal and interannual variations in levels of certain parameters. These were particularly apparent for nitrate, silicate and phytoplankton abundance and composition. Other parameters showed more uniform distributions, with the exception of the 2 stations in New Bedford Harbor. Distributions of phosphate and chl a had concentrations that were generally similar bay-wide on a given sampling date, and over seasons and years for Stns 1 to 6 . However, the signals for elevated concentrations of ammonium, phosphate, and chl a at Stn 7, the sewage outfall, were apparent. High concentrations of these parameters would be expected to reflect sewage effluent, and these data clearly identify the New Bedford sewage outfall as a major eutrophication threat to Buzzards Bay prior to conversion to secondary treatment. However, the increased water transparency and decreased levels of ammonium after conversion to secondary treatment clearly indicate improved water quality at the sewage outfall. Similarly, Borkman \& Smayda (1998) documented a significant increase in Secchi-disk depth in Narragansett Bay from 1972 to 1996 associated with reduced suspended solids due to improved wastewater treatment. A long-term decline in chlorophyll has also been observed in nearby Narragansett Bay (Li \& Smayda 1998, Fulweiler et al. 2007).

Even though nutrient levels were usually lower in the inner harbor of New Bedford than at the sewage outfall, chl a levels at Stn 8 were generally the highest of any of our stations. We suspect that the reason for this is physical. The hurricane dike across the mouth of the inner harbor almost completely encloses it, creating an area somewhat akin to a 'marine lake'. Salinities behind the hurricane dike are typically 1 to $4 \%$ lower than for the rest of the bay, and except for winter, surface temperatures are 1 to $3^{\circ} \mathrm{C}$ higher. Although we are unaware of any substantial study of water exchange between the inner harbor and the rest of the bay, we suspect that circulation is greatly reduced, decreasing washout of inner harbor phytoplankton populations. Thus, phytoplankton and nutrients appear to accumulate in the inner harbor, causing higher chl a concentrations there.

Phytoplankton abundances recorded here for 1988 to 1998 are higher than generally reported from previous studies in other coastal waters of New England, and higher than for the only previous study in Buzzards Bay for 1987-88 (Borkman 1994). The reason for the former is that our preservation of samples with Utermöhl's solution did not destroy the delicate microflagellates and phytoflagellates which so completely dominated phytoplankton numerical abundance (Fig. 10). However, Borkman (1994) also used Utermöhl's preservation, and reported a range of phytoplankton abundance for our Stns 1 to 8 in Buzzards Bay
(Cruises 1 to $17 ; 1987-88$ ) of 0.06 to $4.98 \times 10^{6}{\text { cells } l^{-1}}^{-19}$

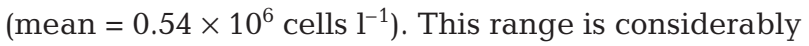
lower than that recorded here $\left(0.012\right.$ to $26.0 \times 10^{6}$ cells $\mathrm{l}^{-1}$ ) for Cruises 18 to 141 (1988 to 1998).

We suspect that the reason for this discrepancy is due to differences in microscope magnifications used in analyses. Borkman (1994) counted phytoplankton from Cruises 1 to 17 at 250×, with occasional examination at $500 \times$ to observe certain taxonomic features needed for identification. For samples from Cruises 18 to 141 , J. Lincoln counted microflagellates at $500 \times$ (using the same Olympus BH3 microscope that Borkman used) or a similar Olympus B201 microscope at $400 \times$. Since phytoplankton samples from Buzzards Bay are usually loaded with extraneous detrital and mineral particles, which can frequently obscure small phytoplankton cells in the $2 \mu \mathrm{m}$ diameter size range, we suspect that Borkman (1994) may have underestimated the abundance of microflagellates (making counts at $250 \times$ ) compared to values presented here, counted at $400 \times$ or $500 \times$.

The patterns of occurrence of various diatom taxa suggest that some of the 'species' recorded for Buzzards Bay may actually represent species complexes. For instance, many records previously attributed to Skeletonema costatum may include several different species in many localities (Sarno et al. 2005, 2007, Zingone et al. 2005). Several different congeneric species may occur in a given location at different times of the year. We suspect that our records for putative S. costatum may encompass a suite of several such congeners, since blooms in Buzzards Bay occurred in various years usually during August and September when the water temperature was at its annual maximum, but also in February 1995 when the water was near freezing, or in May 1994 when the water was just starting to warm. Kooistra et al. (2008) found that Skeletonema spp. from nearby Narragansett Bay included the recently described species S. grethae, collected in May to August, and $S$. japonicum, collected in December. Clarification of such issues for the Skeletonema specimens found in Buzzards Bay will require additional study, using genomic and scanning electron microscopy techniques (Sarno et al. 2005, 2007, Zingone et al. 2005). Such is probably also the case for various HAB taxa, including Pseudo-nitzschia spp., and Alexandrium fundyense and other dinoflagellates.

In conclusion, Buzzards Bay appears to be a favorable habitat for phytoplankton in that it is well-mixed and well-illuminated, and nutrient-replete. Although there were obvious eutrophication signals from the New Bedford sewage outfall prior to secondary treatment, in terms of high ammonium and chl $a$, and low light penetration, the remaining open waters of the estuary appeared to be relatively unaffected by 
sewage. Nutrients and phytoplankton pigments were highly variable in time and space. While most locations away from New Bedford Harbor exhibited similar values on a given day, the stations at the sewage outfall (Stn 7) and inner harbor (Stn 8) usually had much higher values than the rest of the bay. There were also major fluctuations in nutrients and phytoplankton pigments on time scales ranging from every 2 wk to once a month to seasonal to interannual. Consideration of parameter variability in Buzzards Bay is essential for proper understanding and management of this system.

Acknowledgements. We appreciate the funding for intermittent periods of this study provided by the Massachusetts Department of Environmental Protection (DEP) and the Executive Office of Environmental Affairs (EOEA). We also appreciate financial 'bridging' by the University of Massachusetts Dartmouth to maintain continuity of sampling, during periods when continuity of other funding was not maintained. Financial aid for completion of analyses of nutrient and chlorophyll data was provided by NOAA awards: NA04NMF4720339, NA05NMF4721132, and NA06NMF4720096. The views expressed herein are those of the authors and do not necessarily reflect the views of NOAA or any other agencies. Grateful thanks go to present and past Captains of the RV 'Lucky Lady', in chronological order, the late L. Hathaway, J. Gage, Ron Rock, Ray Rock, and their crews. Dozens of undergraduate and graduate students from the University of Massachusetts Dartmouth have participated in this project; we thank them all, but particularly (in approximate chronological order) W. Lima, R. Pierce, L. McInnes, J. Battaglia, M. Lyons, J. Hill, A. S. Chute, M. Semple, C. Mellican, C. S. Heustis, C. James, K. R. Boissonneault, B. Harrison, S. Duclos, J. Darga, J. Woodburne, J. Kang, R. Kessler, J. Fearing, C. Dunn and J. Kieser.

\section{LITERATURE CITED}

Anderson DM (1997) Bloom dynamics of toxic Alexandrium species in the northeastern U.S. Limnol Oceanogr 42: 1009-1022

Anderson DM, Townsend DW, McGillicuddy DJ, Turner JT (eds) (2005) The ecology and oceanography of toxic Alexandrium fundyense blooms in the Gulf of Maine. Deep-Sea Res II 52:2365-2876

Bates SS, Garrison DL, Horner RA (1998) Bloom dynamics and physiology of domoic-acid-producing Pseudo-nitzschia species. In: Anderson DM, Cembella AD, Hallegraeff GM (eds) Physiological ecology of harmful algal blooms. NATO ASI Series, Vol G 41, Springer-Verlag, Berlin, p 267-292

Borkman DG (1994) Phytoplankton and nutrients in Buzzards Bay, Massachusetts, 1987-1988. MS thesis, University of Massachusetts Dartmouth, MA

Borkman DG (2002) Analysis and simulation of Skeletonema costatum (Grev.) Cleve annual abundance patterns in lower Narragansett Bay 1959 to 1996. PhD dissertation, University of Rhode Island, Kingston, RI

Borkman DG, Smayda TJ (1998) Long-term trends in water clarity revealed by Secchi-disk measurements in lower Narragansett Bay. ICES J Mar Sci 55:668-679

Borkman DG, Turner JT (1993) Plankton studies in Buzzards Bay, Massachusetts, USA. II. Nutrients, chlorophyll $a$ and phaeopigments, 1987 to 1990. Mar Ecol Prog Ser 100: 27-34

Borkman DG, Pierce RW, Turner JT (1993) Dinoflagellate blooms in Buzzards Bay, Massachusetts. In: Smayda TJ, Shimizu Y (eds) Toxic phytoplankton blooms in the sea. Elsevier, Amsterdam, p 211-216

Chute AS, Turner JT (2001) Plankton studies in Buzzards Bay, Massachusetts, USA. V. Ichthyoplankton, 1987 to 1993. Mar Ecol Prog Ser 224:45-54

Conover SAM (1956) Oceanography of Long Island Sound, 1952-1954. IV. Phytoplankton. Bull Bingham Oceanogr Coll 15:62-112

Costa JE, Howes BL, Gunn E (1996) Baywatchers: report of the Buzzards Bay citizens' water quality monitoring program 1992-1995. Coalition for Buzzards Bay, New Bedford, MA

Dodge JD (1982) Marine dinoflagellates of the British Isles. Her Majesty's Stationery Office, London

Durbin EG, Krawiec RW, Smayda TJ (1975) Seasonal studies on the relative importance of different size fractions of phytoplankton in Narragansett Bay (USA). Mar Biol 32: 271-287

- Edwards M, Richardson AJ (2004) Impact of climate change on marine pelagic phenology and trophic mismatch. Nature 430:881-884

Fulweiler RW, Nixon SW, Buckley BA, Granger SL (2007) Reversal of the net dinitrogen gas flux in coastal marine sediments. Nature 448:180-182

Gauthier DA, Lincoln JA, Turner JT (2008) Distribution, abundance, and growth of larval tautog Tautoga onitis in Buzzards Bay, Massachusetts, USA. PSZN I: Mar Ecol 29: $76-88$

Geyer WR, Dragos P (1990) Hydrodynamic baseline measurements in New Bedford Harbor. Woods Hole Oceanographic Institution Technical Report WHOI-90-54, Woods Hole, MA

Granéli E, Turner JT (2006) Ecology of harmful algae. Ecological studies 189, Springer, Heidelberg

Guillard RRL (1973) Division rates. In: Stein JR (ed) Phycological methods. Cambridge University Press, Cambridge, p 289-311

Heywood P (1989) Phylum Raphidophyta. In: Margulis L, Corliss JO, Melkonian M, Chapman DJ (eds) Handbook of Protoctista. Jones and Bartlett, Boston, MA, p 318-325

Hill JO (1998) Phytoplankton primary productivity in Buzzards Bay, Massachusetts, 1991-1993. MS thesis, University of Massachusetts, Dartmouth, MA

Howes BL, Goeringer DD (1996) Ecology of Buzzards Bay: an estuarine profile. Biol Rept 31, US Dept Interior, Washington, DC

Howes BL, Williams A, Rasmussen M (1999) Baywatchers II. Nutrient related water quality of Buzzards Bay embayments: a synthesis of Baywatchers monitoring 1992-1998. Coalition for Buzzards Bay, New Bedford, MA

> Karentz D, Smayda TJ (1984) Temperature and seasonal occurrence patterns of 30 dominant phytoplankton species in Narragansett Bay over a 22-year period (1959-1980). Mar Ecol Prog Ser 18:277-293

Karentz D, Smayda TJ (1998) Temporal patterns and variations in phytoplankton community organization and abundance in Narragansett Bay during 1959-1980. J Plankton Res 20:145-168

Kooistra WHCF, Sarno D, Balzano S, Gu H, Andersen RA, Zingone A (2008) Global diversity and biogeography of Skeletonema species (Bacillariophyta). Protist 159:177-193

Li Y, Smayda TJ (1998) Temporal variability of chlorophyll in Narragansett Bay, 1973-1990. ICES J Mar Sci 55:661-667 
Nakamura Y, Turner JT (1997) Predation and respiration by the small cyclopoid copepod Oithona similis: How important is feeding on ciliates and heterotrophic flagellates? J Plankton Res 19:1275-1288

NOAA/EPA (1989) Susceptibility of east coast estuaries to nutrient discharges: Passamaquoddy Bay to Chesapeake Bay. Strategic Assessment of Near Coastal Waters, Summary Report. US National Oceanic Atmospheric Administration/ US Environmental Protection Agency, Washington, DC

Parsons TR, Maita Y, Lalli CM (1984) A manual of chemical and biological methods for seawater analysis. Pergamon Press, Oxford

Pierce RW, Turner JT (1994a) Plankton studies in Buzzards Bay, Massachusetts, USA. III. Dinoflagellates, 1987 to 1988. Mar Ecol Prog Ser 112:225-234

Pierce RW, Turner JT (1994b) Plankton studies in Buzzards Bay, Massachusetts, USA. IV. Tintinnids, 1987 to 1988. Mar Ecol Prog Ser 112:235-240

Rhoads DC, Tenore K, Browne M (1975) The role of resuspended bottom mud in nutrient cycles of shallow embayments In: Cronin LE (ed) Estuarine research, Vol I. Chemistry, biology, and the estuarine system. Academic Press, New York, p 563-579

Riley GA (1941) Plankton studies. IV. Georges Bank. Bull Bingham Oceanogr Coll 7:1-73

Roman MR (1978) Tidal resuspension in Buzzards Bay, Massachusetts. II. Seasonal changes in the size distribution of chlorophyll, particulate concentration, carbon and nitrogen in resuspended particulate matter. Estuar Coast Mar Sci 6:47-53

Ryther JH, Dunstan WM (1971) Nitrogen, phosphorus, and eutrophication in the coastal marine environment. Science 171:1008-1013

Sankaranarayanan S (2007) Modeling the tide and windinduced circulation in Buzzards Bay. Estuar Coast Shelf Sci 73:467-480

Sarno D, Kooistra WHCF, Medlin LK, Percopo I, Zingone A (2005) Diversity in the genus Skeletonema (Bacillariophyceae). II. An assessment of the taxonomy of $S$. costatum-like species with the description of four new species. J Phycol 41:151-176

Sarno D, Kooistra WHCF, Balzano S, Hargraves PE, Zingone A (2007) Diversity in the genus Skeletonema (Bacillariophyceae). III. Phylogenetic position and morphological variability of Skeletonema costatum and Skeletonema grevillei, with the description of Skeletonema ardens sp. nov. J Phycol 43:156-170

SAS (2004) SAS 9.1.3 Help and documentation. SAS Institute, Cary, NC

Editorial responsibility: Peter Verity,

Savannah, Georgia, USA
Signell RP (1987) Tide- and wind-forced currents in Buzzards Bay, Massachusetts. Woods Hole Oceanographic Institution Technical Report, WHOI-87-15, Woods Hole, MA

Smayda TJ (1983) The phytoplankton of estuaries. In: Ketchum $\mathrm{BH}$ (ed) Estuaries and enclosed seas. Elsevier, Amsterdam, p 65-102

Smayda TJ (1984) Variations and long-term changes in Narragansett Bay, a phytoplankton-based coastal marine ecosystem: relevance to field monitoring for pollution assessment. In: White HH (ed) Concepts in marine pollution measurements. University of Maryland Sea Grant Publication, College Park, MD, p 663-679

Smayda TJ (1998) Patterns of variability characterizing marine phytoplankton, with examples from Narragansett Bay. ICES J Mar Sci 55:562-573

Smayda TJ, Borkman DG, Beaugrand G, Belgrano A (2004) Responses of marine phytoplankton populations to fluctuations in marine climate. In: Stenseth NC, Ottersen G, Hurrell JW, Belgrano A (eds) Marine ecosystems and climate variation. The North Atlantic. A comparative perspective. Oxford University Press, Oxford, p 49-58

Sverdrup HU (1953) On conditions for the vernal blooming of phytoplankton. J Cons Int Explor Mer 18:287-295

Tomas CR (ed) (1997) Identifying marine phytoplankton. Academic Press, San Diego, CA

Townsend DW, Cammen LM, Christensen JP, Ackleson SG and others (1991) Seasonality of oceanographic conditions in Massachusetts Bay. Final report to Massachusetts Water Resources Authority, Bigelow Laboratory for Ocean Sciences Technical Report No. 83, Boothbay Harbor, ME

Turner JT, Borkman DG (1993) Plankton studies in Buzzards Bay, Massachusetts, USA. I. Hydrography and bacterioplankton, 1987-1990. Mar Ecol Prog Ser 100:17-26

Turner JT, Hopkins TL (1974) Phytoplankton of the Tampa Bay System. Bull Mar Sci 24:101-121

> Turner JT, Bruno SF, Larson RJ, Staker RD, Sharma GM (1983) Seasonality of plankton assemblages in a temperate estuary. PSZN I: Mar Ecol 4:81-99

Turner JT, Borkman DG, Pierce RW (1995) Should red tide dinoflagellates be sampled using techniques for microzooplankton rather than phytoplankton? In: Lassus P, Arzul G, Erard-Le Denn E, Gentien P, Marcaillou-Le Baut C (eds) Harmful marine algal blooms, Proc 6th Int Conf on Toxic Marine Phytoplankton, Nantes, France, 18-22 October 1993. Lavoisier, Paris, p 737-742

Zingone A, Percopo I, Sims PA, Sarno D (2005) Diversity in the genus Skeletonema (Bacillariophyceae). I. A reexamination of the type material of $S$. costatum with the description of $S$. grevillei sp. nov. J Phycol 41:140-150

Submitted: May 13, 2008; Accepted: October 16, 2008 Proofs received from author(s): January 21, 2009 